\title{
Assessment of VOC absorption in hydrophobic ionic liquids: measurement of partition and diffusion coefficients and simulation of
}

\section{a packed column.}

Alfredo-Santiago Rodriguez Castillo ${ }^{a}$, Pierre-François Biard ${ }^{\mathrm{a}^{*}}$, Solène Guihéneuf ${ }^{\mathrm{b}}$, Ludovic Paquin ${ }^{\mathrm{b}}$, Abdeltif Amrane ${ }^{\mathrm{a}}$, Annabelle Couvert ${ }^{\mathrm{a}}$

aUniv Rennes, Ecole Nationale Supérieure de Chimie de Rennes, CNRS, ISCR - UMR 6226, F-35000 Rennes, France

${ }^{b}$ Univ Rennes, CNRS, ISCR - UMR 6226, F-35000 Rennes, France

\section{Abstract}

Partition coefficients of toluene and dichloromethane (DCM) in 23 hydrophobic ionic liquids (ILs), which can be used potentially for the physical absorption of volatile organic compounds (VOCs), were measured at $298 \mathrm{~K}$. The partition coefficients, expressed as Henry's law constants, were 400 to 1300 times for toluene and 10 to 47 times for DCM lower in the selected ILs than in water. Thus, the toluene and DCM diffusion coefficients were measured in three high potential hydrophobic ILs and in [Bmim] $\left[\mathrm{NTf}_{2}\right]$ using a thermogravimetric microbalance. Diffusivity measurements were performed at $298 \mathrm{~K}$ for toluene and between 278 and 308K for DCM. Diffusion coefficients in ILs, ranging between 1 and $4 \times 10^{-11} \mathrm{~m}^{2} \mathrm{~s}^{-1}$, were from 18 to 90 times lower than in water at $298 \mathrm{~K}$. The diffusion coefficients were correlated to the temperature, the solute molar volume, the IL viscosity and molar volume with an average error of $4.2 \%$. Finally, a $3 \mathrm{~m}$ industrial packed column was simulated for the removal of DCM and toluene in $\left[\mathrm{AllylEt}_{2} \mathrm{~S}\right]\left[\mathrm{NTf}_{2}\right]$ and $[\mathrm{bmim}]\left[\mathrm{NTf}_{2}\right]$, which both present moderate viscosities of nearly $50 \mathrm{mPa} s$ at $293 \mathrm{~K}$. The overall mass-transfer coefficient, the removal efficiency and the pressure drop were calculated and compared to those obtained using other heavy solvents (a silicon

\footnotetext{
* Corresponding author : pierre-francois.biard@ensc-rennes.fr, Tel: + 33223238149
} 
oil and di-(2-ethylhexyl) adipate). This prospective simulation has demonstrated a good potential of ionic liquids for the toluene removal. Nonetheless, the DCM removal efficiencies simulated were lower than 44\%. It suggests that even more efficient ionic liquids can be tuned and synthesized in the future for this specific application.

\section{Keywords}

Ionic liquid; volatile organic compound; diffusion coefficient; partition coefficient; absorption; packed column.

\section{Highlights}

- Toluene partition coefficients in 23 ILs were in the range 0.5-3.5 $\mathrm{Pa} \mathrm{m}^{3} \mathrm{~mol}^{-1}$

- Dichloromethane partition coefficients in 23 ILs were in the range 5-17 $\mathrm{Pa} \mathrm{m}^{3} \mathrm{~mol}^{-1}$

- VOC diffusion coefficients in the range $1-4 \times 10^{-11} \mathrm{~m}^{2} \mathrm{~s}^{-1}$ were measured in $4 \mathrm{ILS}$

- The computed toluene removal efficiency in a packed column was from 52 to $99.6 \%$

- The computed dichloromethane removal efficiency in a packed column was lower than $44 \%$

\section{Graphical abstract}

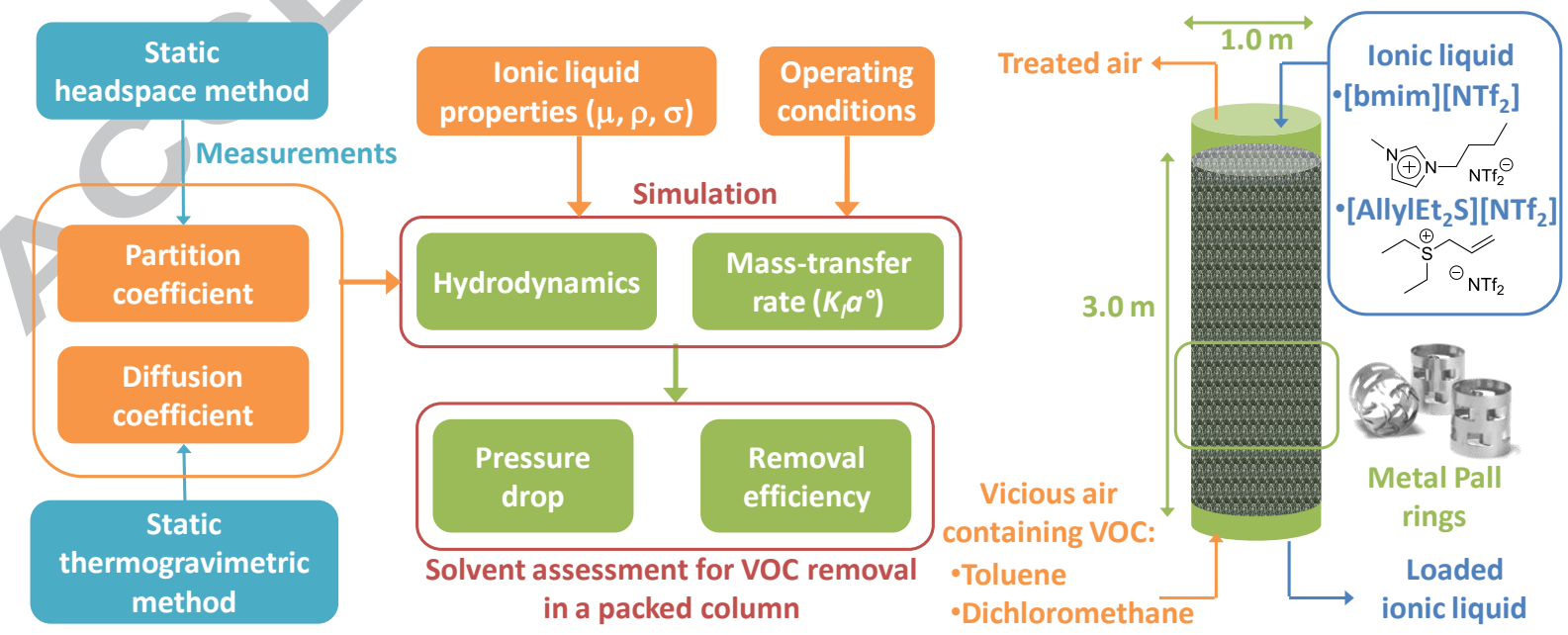




\section{Introduction}

Heavy organic solvents such as silicon oils, di-(2-ethylhexyl) adipate (DEHA), phtalates or ionic liquids (ILs) are gaining attention as potential absorbents for the physical scrubbing of hydrophobic volatile organic compounds (VOCs) from gaseous effluents [1-9]. Indeed, besides good absorption capacities for VOCs, these solvents are advantageously characterized by a low or a null vapor tension, a low miscibility in water and good thermal and chemical stabilities. Furthermore, being non-biodegradable and non-toxic, silicon oils and many ILs can be recycled by a biological process [3, 10-14].

Ionic liquids are non-flammable molten salts consisting of a large organic cation linked to a counterion typically having a melting point at or below $373 \mathrm{~K}$ [15-17]. They show many advantages for bioreactor applications as non-aqueous liquid phases according to their tunable related to their wide range of possible structures. Therefore, they can be designed to fulfill the required criteria for hydrophobic VOCs absorption [18-22] and subsequent biodegradation by a biological material (microorganisms, bacteria, activated sludge, etc.) contained in an aqueous phase in a two-phase partitioning bioreactor $[12,23]$. Their high potential for the absorption of different hydrophobic organic compounds has been already demonstrated through the determination of the partition coefficients at infinite dilution (Henry's law constants) of toluene and dimethyldisulfide (DMDS) in two ILs ([Bmim] $\left[\mathrm{PF}_{6}\right]$ and $\left.[\mathrm{Bmim}]\left[\mathrm{NTf}_{2}\right]\right)$ which ranged between 1.5 and $3.2 \mathrm{~Pa} \mathrm{~m}^{3} \mathrm{~mol}^{-1}[10] . \mathrm{CO}_{2}$ absorption in ionic liquids through partition, and sometimes diffusion coefficients measurement, has also been massively investigated, especially by Shiflett, Yokozeki and their co-workers [24-29]. Nonetheless, prospective studies dealing with VOC absorption in ILs are still scarce and focused on toluene, hydrofluorocarbons, alkanes or alkenes [30-35].

Two main methods can be used to measure diffusion coefficients of solute/solvent systems. A static configuration (without any gas flow) is recommended to avoid convection contributions [27]. The thermogravimetric method measures the solute uptake in the investigated solvent by means of a microbalance. Buoyancy corrections must be taken into account in order to correct the expansion of 
the solvent during the solute absorption [27, 32, 36]. The manometric method measures the pressure decay in a thermo-controlled cell chamber which contains a layer of solvent $[35,37]$.

Nonetheless, these solvents have typically viscosities from 1 to 3 orders of magnitude higher than water, which can alter both their hydrodynamics and mass-transfer performances in usual gas-liquid contactors, especially packed columns which are commonly selected for scrubbing. The lower masstransfer performances observed in viscous solvents are mainly related to lower diffusivities. Indeed, diffusion coefficients 1 or 2 orders of magnitude lower (around $10^{-11} \mathrm{~m}^{2} \mathrm{~s}^{-1}$ ) than those encountered in traditional solvents were measured in ILs [34, 35, 38]. For similar viscosities, diffusivities increase with the molar volume following the order: phosphonium $\left(\approx 600 \mathrm{~cm}^{3} \mathrm{~mol}^{-1}\right)>$ ammonium $\left(\approx 400 \mathrm{~cm}^{3}\right.$ $\left.\mathrm{mol}^{-1}\right)>$ imidazolium $\left(\approx 200 \mathrm{~cm}^{3} \mathrm{~mol}^{-1}\right)$ demonstrating the influence of the amount of free volume $[37,39,40]$. Conventional correlations usually used to estimate diffusion coefficients (Wilke-Chang, Scheibel, etc.) in traditional solvents have shown high discrepancies for ILs $[27,33,35,37]$.

Up to now, the available data about partition and diffusion coefficients of hydrophobic VOCs in a wide selection of ILs specially designed for this application is rather scarce. Furthermore, since the ionic liquids cost is still high, no pilot-plant study has been performed to confirm their potential for VOCs absorption in real gas-liquid contactors such as packed columns. Thus, the aim of this article is to measure the partition and diffusion coefficients of two model hydrophobic VOCs, toluene and dichloromethane (DCM), in an extended panel of 23 ILs presented elsewhere $[9,11]$. Several cationic scaffolds were explored (imidazolium, isoquinolinium, pyrolidinium, morpholium, triazolium and sulfonium) including functionalized or non-functionalized alkyl side chains and associated with various anions $\left(\mathrm{PF}_{6}^{-}, \mathrm{NTf}_{2}^{-}\right.$and $\left.\mathrm{NfO}^{-}\right)$. The partition coefficients in these $23 \mathrm{ILs}$ were determined by a static headspace method. Thus, the diffusion coefficients were measured using a thermogravimetric balance in $[\mathrm{Bmim}]\left[\mathrm{NTf}_{2}\right]$ as a reference IL widely studied in the literature and in three pertinent ionic liquids ([Bmim] $\left[\mathrm{PF}_{6}\right],[\mathrm{Octlq}]\left[\mathrm{NTf}_{2}\right]$ and $\left.\left[\mathrm{AllylEt}_{2} \mathrm{~S}\right]\left[\mathrm{NTf}_{2}\right]\right)$. Experimental diffusion coefficients were compared to those deduced by conventional correlations and a new correlation was presented. 
Finally, the hydrodynamics and mass-transfer in a packed column fed with $[\mathrm{Bmim}]\left[\mathrm{NTf}_{2}\right]$ and $\left[\right.$ AllylEt $\left.{ }_{2} \mathrm{~S}\right]\left[\mathrm{NTf}_{2}\right]$ were simulated for DCM and toluene absorption. 


\section{Material and methods}

\subsection{Chemical products}

The 23 ILs investigated were synthesized following a methodology previously described [11]. Chemical structures and key physical properties were also reported $[9,11]$. Toluene and dichloromethane (DCM) with a purity higher than $99 \%$ were purchased from Acros Organics (Belgium).

\subsection{Measurement of the partition coefficients at infinite dilution}

\subsubsection{Presentation of the static headspace method}

VOC/IL partition coefficients were deduced from the gas $\left(C_{G}\right.$ in $\mathrm{mol} \mathrm{m}^{-3}$ at $298 \mathrm{~K}$ and 1 bar $)$ and liquidphase $C_{L}\left(\mathrm{~mol} \mathrm{~m}^{-3}\right)$ VOC concentrations obtained at the equilibrium in glass vials of $22 \mathrm{~mL}$. The partition coefficients were expressed as $K_{H}\left(\mathrm{~Pa} \mathrm{~m}^{3} \mathrm{~mol}^{-1}\right)$ and $K_{H^{\prime}}$ (dimensionless) defined as follows:

$K_{H}{ }^{\prime}=C_{G} / C_{L}$

$K_{H}=K_{H}{ }^{\prime} \times R \times T$

Eq. 2

For each VOC/IL systems, six $22 \mathrm{~mL}$ vials containing a different initial amount of VOC were prepared by the following procedure. $1 \mathrm{~mL}$ of a stock solution of toluene or DCM diluted in IL at $5 \mu \mathrm{gL}^{-1}$ was prepared in a syringe Hamilton AccuDil ${ }^{\mathrm{TM}}$ MicroLab $^{\circledR}$. In parallel, 260 to $460 \mu \mathrm{L}$ of pure IL were introduced in $22 \mathrm{~mL}$ glass vials. These vials were closed with PTFE/silicone septa (Sigma-Aldrich, USA) and sealed with $20 \mathrm{~mm}$ crimp seals. Thus, 40 to $240 \mu \mathrm{L}$ of the toluene or DCM stock solution were introduced to complete the IL volume at $500 \mu \mathrm{L}$ in all the bottles. The bottles were maintained under a constant agitation (10 rpm) at $298 \mathrm{~K}$ for $72 \mathrm{~h}$ using a rotator (Labinco Model L28"TESTTUBE) to reach equilibrium. Then, the headspace VOC concentration $\left(C_{G}\right)$ was quantified by GC-FID and $C_{L}$ was deduced from the mass balance knowing the initial amount of $\mathrm{VOC}$ and both the liquid volume and 
the headspace volume. Control bottles devoid of IL were also monitored in order to ensure gas tightness.

\subsubsection{Analytical procedures}

The VOC concentration in the gas-phase was quantified by gas chromatography (ThermoScientificFocus GC, USA). The chromatograph was equipped with a RTX-1 (15 m x 0.32 mmID) column (Restek, USA) and a flame ionization detector. The injector and detector temperatures were maintained at $473 \mathrm{~K}$ and $523 \mathrm{~K}$, respectively. For both toluene and DCM, the oven temperature was maintained at $353 \mathrm{~K} . \mathrm{N}_{2}$ was employed as carrier gas at $1.0 \mathrm{~mL} \mathrm{~min}^{-1}$.

\subsection{Measurement of the diffusion coefficients}

\subsubsection{Presentation of the method}

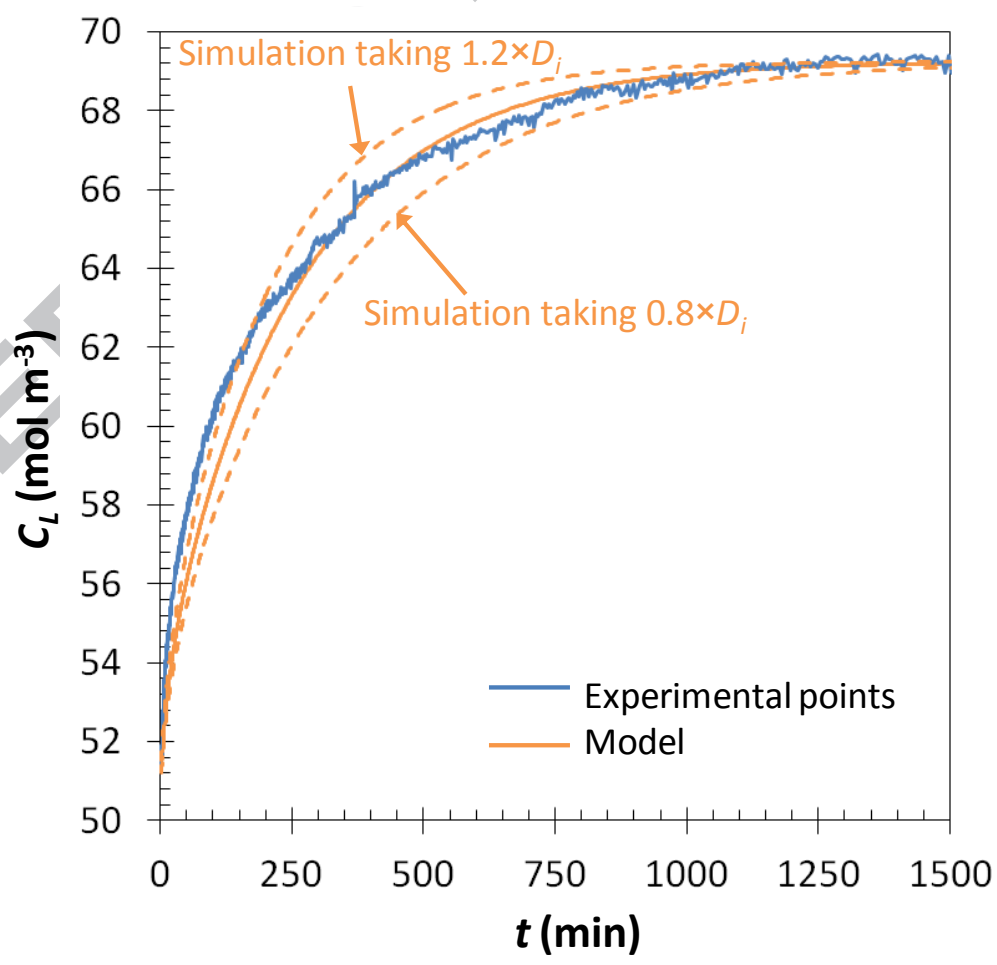

Figure 1. Example of a static absorption experiment and analysis of the toluene uptake sensitivity to the diffusion coefficient. The determined diffusion coefficient was over and underestimated by $20 \%$ ([Octlq][NTf 2$]$ at 350 Pa and at $298 \mathrm{~K})$. 
A thermogravimetric microbalance (IGA 003 provided by Hiden Isochema Ltd, Japan) was used to measure the diffusion coefficients. The IGA 003 can operate in both dynamic and static configurations. The main characteristics of this apparatus are presented in the supporting material (Part 1.1) and extensively in the article of Shiflett and Yokozeki [27]. An enhanced pressured stainless steel (SS316LN) sample container capable of operation from $10^{-7}$ mbar to 10 bar and from 273 to 773 $\mathrm{K}$ was installed. Approximately $70 \mathrm{mg}$ of an ionic liquid sample was placed into the sample container and the reactor was then sealed. Samples were dried under deep vacuum $\left(10^{-7} \mathrm{mbar}\right)$ before starting measurements in order to remove any trace of water by following the procedure presented in the supporting material (part 1.2). IGA 003 was operated in a static mode in a pure VOC atmosphere at various pressures. Thus, when the desired temperature was achieved and stable and when the IL sample was completely dried, the admittance and exhaust valves were automatically opened and closed to introduce the VOC gas atmosphere inside the reactor targeting a constant VOC pressure of $50 \mathrm{~Pa}$. The solute uptake in the investigated solvent was registered over time until a plateau corresponding to the thermodynamic equilibrium was reached. Then six additional set-points (at 200, $350,500,650,800$ and $950 \mathrm{~Pa}$ ) were recorded for each solute/IL couples at each temperature. Low pressures were selected in this study to limit the solute mole fraction in the IL $(<6 \%)$ to simulate realistic conditions similar of those implemented in an industrial process. Besides, according to Roustan (2003), below a $10 \%$ molar fraction, the solute diffusion coefficient in the solvent can be considered at infinite dilution [41]. During each experiment, the sample mass variation allows to determine the mass of solute absorbed in the IL and then the liquid concentration knowing the liquid volume. Buoyancy corrections accounting for gas densities variations with the temperature and pressure have been considered using the procedure of Shifflet and Yokozeki [27]. The characteristics of the microbalance components and the values of the correction factors used for buoyancy correction are detailed in the supporting material (part 1.3, Tables S.2 and S.3). The pressure ramp was set at $100 \mathrm{mbar}^{\mathrm{min}}{ }^{-1}$ and the temperature ramp was set at $2.0 \mathrm{~K} \mathrm{~min}^{-1}$. For each pressure implemented, the plateau was reached in approximately 30-35 hours. To ensure sufficient time for 
gas-liquid equilibrium, the ionic liquid samples were maintained at the set-point for at least $24 \mathrm{~h}$ with a maximum time-out of $72 \mathrm{~h}$.

The influence of the temperature was assessed for DCM from 278.15 to $308.15 \mathrm{~K}$ in $10 \mathrm{~K}$ interval for [Octlq][NTf $f_{2}$. The influence of the IL physical properties was assessed for toluene at $298.15 \mathrm{~K}$. One example of a breakthrough curve corresponding to the toluene absorption in [Octlq] $\left[\mathrm{NTf}_{2}\right.$ ] at $350 \mathrm{~Pa}$ and at $298 \mathrm{~K}$ is presented Fig. 1 . The others examples are presented in the supporting material (Figs S1-S8).

\subsubsection{Mathematical treatment}

The breakthrough curves corresponding to the VOC uptake (Fig. 1 and part 1.4 of the supplementary material) where treated using the diffusion model presented by Shiflett and Yokozeki [27]. The IL initial volume placed in the microbalance vessel was deduced from its dried mass and density at the working temperature. Thus, the initial liquid height $(L)$ was calculated knowing the vessel diameter $(80 \mathrm{~mm})$. The model developed by Yokozeki assumed that [42]:

- The convective flow was negligible;

- A one-dimensional diffusion process can be considered (z-axis);

- The temperature and pressure inside the reactor remained constant over time;

According to the Fick's law without convection:

$\frac{\partial C_{L}}{\partial t}=D_{i} \frac{\partial^{2} C_{L}}{\partial z^{2}}$ Eq. 3

Where $C_{L}\left(\mathrm{~mol} \mathrm{~m}^{-3}\right)$ is the concentration of the solute in the ionic liquid, $t(\mathrm{~s})$ is the time, $z(\mathrm{~m})$ is the vertical coordinate and $D_{i}$ is the diffusion coefficient $\left(\mathrm{m}^{2} \mathrm{~s}^{-1}\right)$. The initial and boundary conditions were:

$C_{L}=C_{L, O}$ when $\mathrm{t}=0$ and $0<z<\mathrm{L}$ Eq. 4

$C=C_{L, S}$ when $\mathrm{t}>0$ and $z=0$ Eq. 5 
$\frac{\partial C_{L}}{\partial t}=0$ at $z=\mathrm{L}$

Eq. 6

$L(\mathrm{~m})$ is the depth of the ionic liquid in the vessel, $z=0$ corresponds to the vapor-liquid boundary, $C_{L, 0}$ is the known initial homogeneous solute concentration and $C_{L, S}$ is the solute saturation concentration $\left(\mathrm{mol} \mathrm{m}{ }^{-3}\right)$. The VOC concentration in the $\mathrm{IL}$ at any time $(C)$ can be deduced from the following analytical solution:

$C_{L}=C_{L, 0}\left[1-2\left(1-\frac{C_{L, 0}}{C_{L, S}}\right) \sum_{n=0}^{\infty} \frac{\exp \left(-\lambda_{n}^{2} D_{i} t\right) \sin \lambda_{n} z}{L \lambda_{n}}\right]$ Eq. 7

Where $\lambda_{n}=\left(n+\frac{1}{2}\right) \pi / L$

Few iterations ( $n=15)$ were necessary to get the convergence. A non-linear regression was performed to determine $D_{i}$ for each experiment trying to minimize the least squares objective function between the measured values of $C_{L}$ and those deduced from Eq. 7 using the Excel Solver (time $\max =100 \mathrm{~s}$, iteration $=1000$, precision $10^{-7}$, tolerance $=1 \%$, convergence $=10^{-5}$, quadratic estimations, central derivation and conjugated gradient method). 


\section{Results and discussion}

\subsection{Determination of the VOC/IL partition coefficients}

Table 1. Toluene and DCM partition coefficients measured at 298K. The determination coefficient $\left(R^{2}\right)$ corresponds to the linear regression between $C_{G}$ vs $C_{L}$ based on six points corresponding to six vials with different initial amounts of VOC. Data in bold correspond to the four

ILs selected for diffusion coefficient measurements (Part 3.2).

\begin{tabular}{|c|c|c|c|c|c|c|c|c|}
\hline \multirow[b]{2}{*}{ voc } & \multicolumn{4}{|c|}{ Toluene } & \multicolumn{4}{|c|}{ Dichloromethane } \\
\hline & $\frac{K_{H}}{\mathrm{~Pa} \mathrm{~m}^{3} \mathrm{~mol}^{-1}}$ & $10^{4} \times K_{H}^{\prime}$ & $\begin{array}{l}\mathbf{R}^{2} \\
\%\end{array}$ & $A R^{*}$ & $\frac{K_{H}}{\mathrm{~Pa} \mathrm{~m}^{3} \mathrm{~mol}^{-1}}$ & $10^{4} \times K_{H}^{\prime}$ & $\begin{array}{l}\mathrm{R}^{2} \\
\%\end{array}$ & $A R$ \\
\hline Water $^{+}$ & 677 & $2.73 \times 10^{3}$ & - & 1 & 243 & $9.79 \times 10^{3}$ & - & 1 \\
\hline$[\mathrm{Bmim}]\left[\mathrm{NTf}_{2}\right]$ & 1.44 & 5.81 & 99.86 & 470 & 11.58 & 46.71 & 99.46 & 21.0 \\
\hline$[\mathrm{Bmim}]\left[\mathrm{PF}_{6}\right]$ & 2.42 & 9.76 & 99.79 & 280 & 10.46 & 42.26 & 99.74 & 23.2 \\
\hline$[\mathrm{Bmim}][\mathrm{NfO}]$ & 2.81 & 11.35 & 99.62 & 241 & 13.96 & 56.32 & 98.83 & 17.4 \\
\hline$[\mathrm{nPrmim}]\left[\mathrm{NTf}_{2}\right]$ & 0.73 & 2.95 & 99.58 & 927 & 12.46 & 50.26 & 99.97 & 19.5 \\
\hline [iPentmim] $\left[\mathrm{PF}_{6}\right]$ & 2.56 & 10.31 & 99.77 & 264 & 10.70 & 43.15 & 99.70 & 22.7 \\
\hline [iPentmim][NTf $\left.{ }_{2}\right]$ & 0.63 & 2.54 & 99.58 & 1075 & 11.15 & 44.99 & 99.74 & 21.8 \\
\hline [Butenylmim] $\left[\mathrm{PF}_{6}\right]$ & 3.66 & 14.77 & 99.43 & 185 & 9.96 & 43.31 & 99.60 & 24.4 \\
\hline [Butenylmim][NTf $\left.{ }_{2}\right]$ & 1.91 & 7.71 & 99.67 & 354 & 12.00 & 48.41 & 99.94 & 20.3 \\
\hline [Butenylmim][NfO] & 3.13 & 12.62 & 99.96 & 216 & 5.23 & 21.09 & 99.95 & 46.5 \\
\hline$[\mathrm{MeOEmim}]\left[\mathrm{NTf}_{2}\right]$ & 1.92 & 7.75 & 99.89 & 353 & 15.52 & 62.59 & 99.67 & 15.7 \\
\hline [EtOEmim] $\left[\mathrm{NTf}_{2}\right]$ & 1.66 & 6.70 & 99.20 & 408 & 12.28 & 49.54 & 99.86 & 19.8 \\
\hline$\left[\right.$ MeOEOEmim] $\left[\mathrm{NTf}_{2}\right]$ & 2.02 & 8.16 & 99.58 & 335 & 12.97 & 52.34 & 99.78 & 18.7 \\
\hline$[\mathrm{MeOEmim}][\mathrm{NfO}]$ & 0.78 & 3.16 & 99.91 & 868 & \multicolumn{4}{|c|}{ Undetermined } \\
\hline$\left[\right.$ Octlq] $\left[\mathrm{NTf}_{2}\right]$ & 0.50 & 2.01 & 99.93 & 1354 & 9.96 & 40.16 & 99.57 & 24.4 \\
\hline$\left[\right.$ Declq] $\left[\mathrm{NTf}_{2}\right]$ & 0.52 & 2.11 & 99.93 & 1302 & 5.09 & 20.52 & 99.84 & 47.7 \\
\hline$[\mathrm{MeOElq}]\left[\mathrm{NTf}_{2}\right]$ & 1.37 & 5.54 & 98.21 & 494 & 12.45 & 50.23 & 99.55 & 19.5 \\
\hline [EtOElq] $\left[\mathrm{NTf}_{2}\right]$ & 0.53 & 2.12 & 99.74 & 1277 & 12.27 & 49.51 & 99.68 & 19.8 \\
\hline$\left[\mathrm{CNC}_{3} \operatorname{mim}\right][\mathrm{NTf} 2]$ & 3.12 & 12.60 & 99.87 & 217 & 15.48 & 62.44 & 99.71 & 15.7 \\
\hline [BMTriaz] $\left[\mathrm{NTf}_{2}\right]$ & 0.95 & 3.84 & 99.73 & 713 & 14.13 & 56.99 & 99.72 & 17.2 \\
\hline$\left[\mathrm{CF}_{3} \mathrm{CF}_{2} \mathrm{BT}\right.$ riaz $]\left[\mathrm{NTf}_{2}\right]$ & 0.57 & 2.31 & 99.09 & 1188 & 17.00 & 68.60 & 99.51 & 14.3 \\
\hline$\left[\right.$ BMPyrr] $\left[\mathrm{NTf}_{2}\right]$ & 1.76 & 7.10 & 99.78 & 385 & 10.51 & 42.41 & 99.88 & 23.1 \\
\hline [AllylEt $\left.{ }_{2} \mathrm{~S}\right]\left[\mathrm{NTf}_{2}\right]$ & 0.88 & 3.56 & 99.73 & 769 & 12.18 & 49.14 & 99.93 & 20.0 \\
\hline$\left[\right.$ MeOEMMorph] $\left[\mathrm{NTf}_{2}\right]$ & 0.75 & 3.01 & 99.48 & 903 & 9.35 & 37.72 & 99.30 & 26.0 \\
\hline [EtOEMMorph][NTf $\left.{ }_{2}\right]$ & 0.81 & 3.25 & 99.14 & 836 & 16.92 & 68.25 & 99.40 & 14.4 \\
\hline
\end{tabular}

\footnotetext{
${ }^{*} A R$ is the affinity ratio defined as $K_{H}$ in water divided by $K_{H}$ in IL.

${ }^{+}$At $298 \mathrm{~K}$ according to [3].
} 
The VOC/ILs partition coefficients at infinite dilution were measured by the static headspace method using six vials prepared with different initial amount of VOC. At the equilibrium, the gas concentration was proportional to the liquid concentration according to the Henry's law with determination coefficient from $98.8 \%$ to $99.95 \%$. Thus, the dimensionless partition coefficients $\left(K_{H}^{\prime}\right)$ were deduced from the slope of the linear regression between $C_{G}$ vs $C_{L}$ (Table 1 ). The results show that toluene partition coefficients in hydrophobic ILs were roughly in the range 0.5-4 Pa m $\mathrm{mol}^{-1}$ (from 200 to 1400 times lower than in water) and are particularly competitive. These results are supported by the fact that toluene is very hydrophobic (octanol-water partition coefficient of 2.73) and can involve potential $\pi$-stacking interactions with ionic liquids. The measured partition coefficient for the system toluene/[Bmim] $\left[\mathrm{NTf}_{2}\right]$ was $5.0 \%$ lower than the value reported by Quijano et al. and 2.5 times higher than the value reported by Bedia et al. [23, 43]. The quite high discrepancy observed with Bedia et al. (2013) can be justified by the fact that they used a dynamic method in which aerodynamic drag forces can biased the results \{Bedia\}[27]. For the system toluene/[Bmim] $\left[\mathrm{PF}_{6}\right]$, the partition coefficient was $1.6 \%$ higher than the value reported by Quijano et al. [23]. Being less hydrophobic than toluene and without potential $\pi$ interactions, the DCM partition coefficients were from 1.67 to 30 times higher than the toluene partition coefficients, in the range from 5 to $17 \mathrm{~Pa} \mathrm{~m}^{3} \mathrm{~mol}^{-1}$, but they remain significantly lower than in water (from 14 to 50 times). The toluene partition coefficients in the ionic liquids are close to those determined in other heavy solvents such as DEHA and silicon oils. However, the DCM partition coefficients in ionic liquids are in many cases higher than the one measured in DEHA (4.73 $\mathrm{Pa} \mathrm{m}^{3} \mathrm{~mol}^{-1}$ at 293K) and close to the one in a silicon oil, namely polydimethylsiloxane (PDMS) 50 [1].

Both the anion nature and cation structure strongly influence the toluene and DCM partition coefficients, sometimes with similar effects and sometimes with adverse effects (Table 2). These results suggest that the IL selection for a practical application containing a mixture of different VOCs should not be based on the determination of only one partition coefficient with a model VOC, such as toluene which has been often considered in previous studies. The worst affinities are obtained with 
the $\mathrm{NfO}^{-}$anion, whereas $\mathrm{Ntf}_{2}^{-}$and $\mathrm{PF}_{6}^{-}$anions are respectively the most interesting for toluene and DCM. For both DCM and toluene, the best affinities are observed with the isoquinolium cation and the worst affinities with the triazolium and pyridinium-based ionic liquids, showing that the affinities are directly related to the size core, and thus intermolecular and electrostatic forces. As expected, a modification of the structure of the alkyl chain of the cation significantly influences the partition coefficients as it is summarized in Table 2.

Table 2. Comparison of the influence of the anion nature and cation structure of the IL on the toluene and DCM affinities.

\begin{tabular}{ccc}
\hline Parameter & Influence on the toluene affinity & Influence on the DCM affinity \\
\hline Influence of the anion & {$\left[\mathrm{NTf}_{2}\right]>^{*}\left[\mathrm{PF}_{6}\right]>[\mathrm{NfO}]$} & {$[\mathrm{PF}]>\left[\mathrm{NTf} f_{2}\right]>[\mathrm{NfO}]$} \\
Influence of the cation core & {$[\mathrm{lq}]>[\mathrm{Morph}]>\left[\mathrm{Tria}_{6}\right]>[\mathrm{im}]>[\mathrm{Pyrr}]$} & {$[\mathrm{lq}]>[\mathrm{Morph}]>[\mathrm{im}]>[\mathrm{Triaz}]>[\mathrm{Pyrr}]$} \\
$-\mathrm{C}=\mathrm{C}$ - in the alkyl chain & + & + \\
$-\mathrm{CH}_{3}$ in the alkyl chain & + with $\left[\mathrm{NTf}_{2}\right]$ & + with $\left[\mathrm{NTf}_{2}\right]$ \\
& - with $\left[\mathrm{PF}_{6}\right]$ & - with $\left[\mathrm{PF}_{6}\right]$ \\
$-\mathrm{CN}$ in the alkyl chain & - at least with $\left[\mathrm{NTf}_{2}\right]$ & - at least with $\left[\mathrm{NTf}_{2}\right]$ \\
$-\mathrm{CH}_{2}$ - in the alkyl chain & - at least with $\left[\mathrm{NTf}_{2}\right]$ & + at least with $\left[\mathrm{NTf}_{2}\right]$ \\
Alkyl chain length & - & + \\
Ether in the alkyl chain & - & - \\
& $\mathrm{ROC}_{2} \mathrm{H}_{7}>\mathrm{ROCH}_{3}$ & $\mathrm{ROC}_{2} \mathrm{H}_{7}>\mathrm{ROCH}_{3}$ \\
\hline
\end{tabular}

Three ionic liquids combine high affinities for VOCs with a good potential for a biological regeneration according to Rodriguez Castillo et al.: [Octlq][NTf $\left.f_{2}\right]$, $\left.\mathrm{Bmim}\right]\left[\mathrm{PF} \mathrm{F}_{6}\right]$ and $\left[\mathrm{AllylEt}_{2} \mathrm{~S}\right]\left[\mathrm{NTf}_{2}\right]$ [11-13]. Thus, [Bmim][NTf 2 as a model IL commonly described in the literature, and these three ILs were selected for diffusion coefficients measurement.

\subsection{Diffusion coefficients measurement}

\subsubsection{Results}

Toluene diffusion coefficients at $298 \mathrm{~K}$ were measured in the four selected ILs to assess the influence of their properties. The influence of the temperature was assessed with the $D C M /[O c t \mid q]\left[N T f_{2}\right]$

\footnotetext{
* $>$ means "better than"

$++(-)$ means that this factor positively (negatively) influences the affinity with lower (higher) partition coefficients.
} 
system. All the breakthrough curves corresponding to the solute uptakes are presented as supplementary material (Figs S1-S8). At a given temperature, the pressure had no significant influence on the diffusion coefficient between $200 \mathrm{~Pa}$ and $950 \mathrm{~Pa}$ (Tables S.4 and S.5). It validates the assumption of an infinite dilution for a VOC mole fraction lower than $10 \%$; otherwise, the diffusion coefficients would have been correlated to the mole fraction and the pressure. The average diffusion coefficients at each temperature are therefore summarized in Table 3. On the one hand, the significant dispersion of the data at different pressures (with relative standard deviations RSD from 4 to $17 \%$ ) is justified by the experimental uncertainties and the low sensitivity of the mass-transfer rate to the diffusion coefficient. Indeed, Fig. 2, which simulates breakthrough curves for over and underestimated diffusion coefficients by $20 \%$, shows a limited influence. On the other hand, this uncertainty has a limited impact on practical applications since the mass-transfer rate and the gasliquid contactor design have a limited sensitivity to the liquid diffusion coefficient (part 3.3.5 and [44]). The determined toluene diffusivity in $[\mathrm{Bmim}]\left[\mathrm{NTf}_{2}\right]$ at $298 \mathrm{~K}$ was $81 \%$ lower than the value found by Bedia et al. who used a not recommended dynamic method [27, 43].

Table 3. Average diffusion coefficients measured. The raw results at different pressures are listed on Tables S.4 and S.5. RE corresponds to the relative error between the modeled and experimental diffusion coefficients.

\begin{tabular}{|c|c|c|c|c|c|c|}
\hline \multirow[b]{2}{*}{ voc } & \multirow[b]{2}{*}{ IL } & \multirow[b]{2}{*}{$\begin{array}{c}\mathrm{T} \\
\text { (K) }\end{array}$} & \multicolumn{2}{|c|}{ Experimental } & \multicolumn{2}{|c|}{ Model (Eq. 8) } \\
\hline & & & $\begin{array}{l}10^{11} \times D_{i} \\
\left(\mathrm{~m}^{2} \mathrm{~s}^{-1}\right)\end{array}$ & RSD (\%) & $\begin{array}{l}10^{11} \times D_{i} \\
\left(\mathrm{~m}^{2} \mathrm{~s}^{-1}\right)\end{array}$ & "RE (\%) \\
\hline \multirow{4}{*}{ Toluene $^{+}$} & {$[\mathrm{Octlq}]\left[\mathrm{NTf}_{2}\right]$} & 298.15 & $0.98 \pm 0.17$ & 17 & 0.965 & -1.54 \\
\hline & {$[\mathrm{Bmim}]\left[\mathrm{NTf}_{2}\right]$} & 298.15 & $3.42 \pm 0.48$ & 14 & 4.01 & +17.2 \\
\hline & {$[\mathrm{Bmim}]\left[\mathrm{PF}_{6}\right]$} & 298.15 & $1.33 \pm 0.26$ & 27 & 1.32 & -0.79 \\
\hline & {$\left[\right.$ AllylEt $\left.{ }_{2} \mathrm{~S}\right]\left[\mathrm{NTf}_{2}\right]$} & 298.15 & $4.86 \pm 0.92$ & 19 & 4.34 & -10.7 \\
\hline \multirow{4}{*}{$\mathrm{DCM}^{\ddagger}$} & \multirow{4}{*}{ [Octlq] $\left[\mathrm{NTf}_{2}\right]$} & 278.15 & $0.88 \pm 0.06$ & 7 & 0.876 & -0.42 \\
\hline & & 288.15 & $1.53 \pm 0.15$ & 10 & 1.51 & -1.46 \\
\hline & & 298.15 & $2.53 \pm 0.28$ & 11 & 2.51 & -0.93 \\
\hline & & 308.15 & $4.06 \pm 0.17$ & 4 & 4.04 & +0.50 \\
\hline
\end{tabular}

\footnotetext{
* Average relative error of $4.2 \%$.

${ }^{+} D_{\text {toluene }}=89.0 \times 10^{-11} \mathrm{~m}^{2} \mathrm{~s}^{-1}$ in water at $298 \mathrm{~K}$ [1].

${ }^{\ddagger} D_{D C M}=127 \times 10^{-11} \mathrm{~m}^{2} \mathrm{~s}^{-1}$ in water at $298 \mathrm{~K}$ [1].
} 


\subsubsection{Correlation between diffusion coefficients, temperature and physico- chemical properties}

Table 4. Correlations for diffusion coefficient calculation. Adapted from [33, 45, 46].

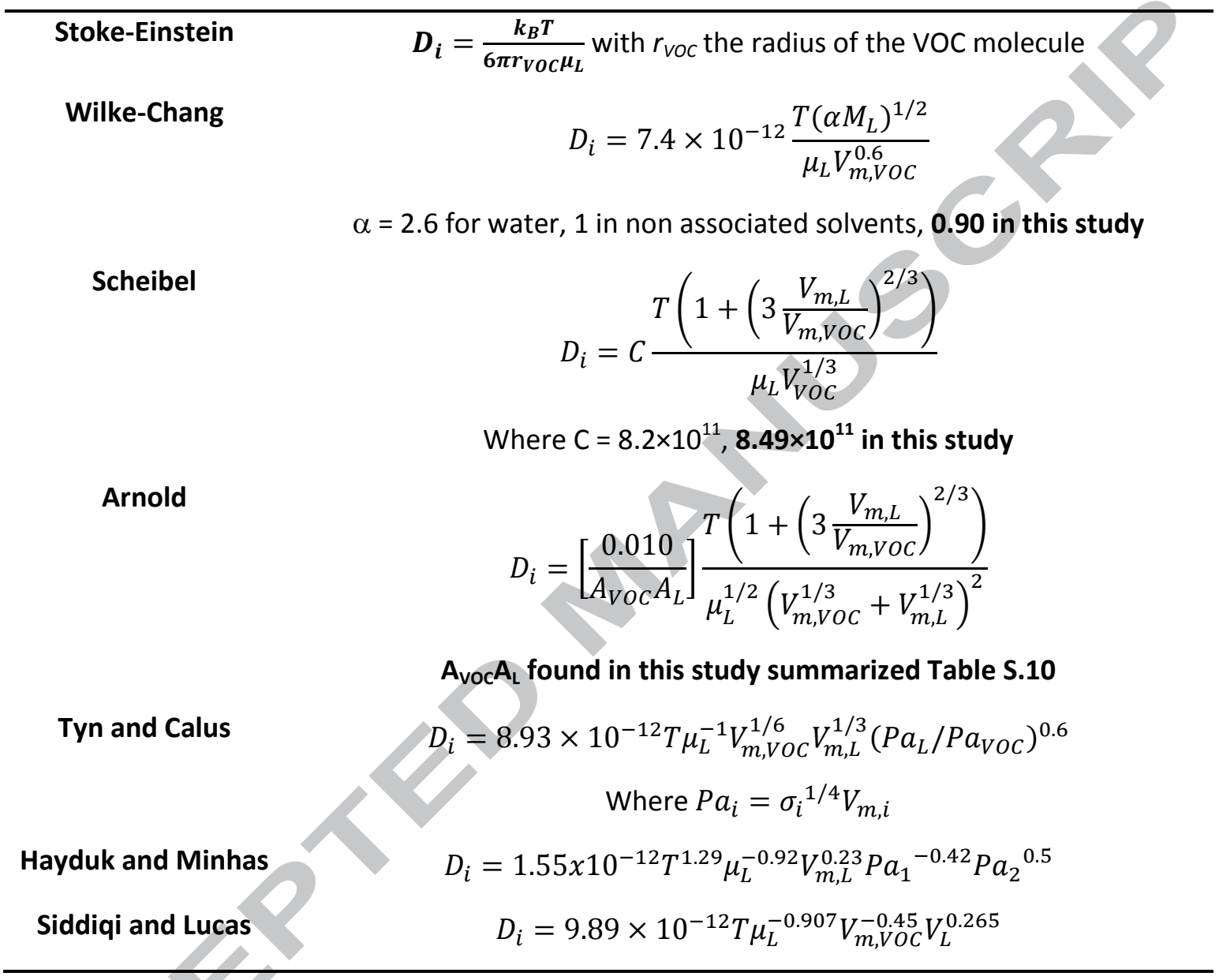

Several theoretical and semi-empirical correlations (Table 4) predict that diffusion coefficients are inversely proportional to the solvent viscosity. The viscosities of the selected ILs are from 50 to more than 600 times higher (Table 5) than the water viscosity but the measured diffusion coefficients are only from 18 to 90 times lower than in water at 298K. It shows that the large viscosities are partly

\footnotetext{
${ }^{*} V_{m, i}$ is the molar volume of the species i (VOC or solvent) in $\mathrm{cm}^{3} \mathrm{~mol}^{-1}, \mu_{L}$ is the solvent viscosity in $\mathrm{mPa} \mathrm{s}^{-1}, \mathrm{~Pa}$ is the parachor of the species $\mathrm{i}$ in $\mathrm{g}^{0.25} \mathrm{~cm}^{3} \mathrm{~mol}^{-1} \mathrm{~s}^{-0.5}, T$ is in $\mathrm{K}, \mathrm{A}_{\mathrm{i}} \alpha$ and $\mathrm{C}$ are dimensionless constants.
} 
compensated by higher molar volumes (roughly 10 to 20 times higher than water). Besides, according to all these theories, the diffusion coefficient is proportional to the temperature and decrease with the solute molar volume with different significances.

Table 5. Physico-chemical properties at $293 \mathrm{~K}$ of the four ILs selected for diffusion coefficients measurement.

\begin{tabular}{|c|c|c|c|c|c|}
\hline Solvent & $M_{L}\left(\mathrm{~g} \mathrm{~mol}^{-1}\right)$ & $\mu_{\mathrm{L}}$ (mPa s) & $\rho_{L}\left(\mathrm{~kg} \mathrm{~m}^{-3}\right)$ & $\sigma_{L}\left(\mathrm{mN} \mathrm{m}^{-1}\right)$ & $V_{m, L}\left(\mathrm{~cm}^{3} \mathrm{~mol}^{-1}\right)$ \\
\hline$\left[\right.$ AllylEt $\left.{ }_{2} \mathrm{~S}\right]\left[\mathrm{NTf}_{2}\right]$ & 411.4 & 50.9 & 1440.5 & 32.2 & 287 \\
\hline$[\mathrm{Bmim}]\left[\mathrm{NTf}_{2}\right]$ & 419.4 & 58.8 & 1441.3 & 32.6 & 292 \\
\hline$[\mathrm{Bmim}]\left[\mathrm{PF}_{6}\right]$ & 284.2 & 230.1 & 1373.0 & & 208 \\
\hline$\left[\right.$ Octlq] $\left[\mathrm{NTf}_{2}\right]$ & 522.5 & 620.6 & 1332.7 & 31.1 & 392 \\
\hline
\end{tabular}

The measured diffusion coefficients were compared to those calculated from the correlations listed in Table 4. The molar volumes of the solvents at their boiling point, which were unknown, were required. Therefore, the molar volumes were calculated at the working temperature. The results are summarized in the supplementary material (Tables S.6 and S.7). In agreement with the observations of other studies $[27,33-35,43,45,47]$, these correlations developed for conventional solvents poorly fit the diffusion coefficients in heavy solvents. Indeed, the average absolute relative error ranged from 21 to $65 \%$ for the toluene diffusion coefficients (with relative error either positive or negative) and from 61 to $91 \%$ (with only negative relative error) for the DCM diffusion coefficients (Tables S.8 and S.9). Since the correlations of Wilke-Chang, Scheibel and Arnold contain empirical fitting variables ( $\alpha, C, A_{V o c} A_{L}$, Table 4$)$, these ones were optimized to minimize the least square objective function between the calculated and measured diffusion coefficients (Tables S.10 and S.11). Reliable values of $\alpha, C$ and $A_{v o c} A_{L}$ close to the initial values were obtained (Table 4). However, this procedure did not allow to significantly improve the accuracy of the predictions. These discrepancies emphasize that the correlations of the literature poorly correlate the diffusion coefficients in ILs to the various influential parameters (temperature $\mathrm{T}$, solute and solvents molar volume $V_{m, V o c}$ and $V_{m, L}$, solvent viscosity $\mu_{L}$ ). Thus, a power-law function similar to the equation of Siddiqi-Lucas, was developed 
trying to minimize the least square objective function between the model and the experimental diffusion coefficients:

$D_{\mathrm{i}}=7.21 \times 10^{-12} \times T^{1.63} \times \mu_{\mathrm{L}}^{-0.702} \times V_{m, L}^{0.510} \times \mathrm{V}_{\mathrm{m}, \mathrm{VOC}}{ }^{-1.623}$ Where the diffusivity $\left(D_{i}\right)$ is in $\mathrm{m}^{2} \mathrm{~s}^{-1}$, the viscosity $\mu_{L}$ is in $\mathrm{mPa}$ s and the molar volumes $V_{m}$ are in $\mathrm{cm}^{3}$ $\mathrm{mol}^{-1}$. The average relative error of $4.2 \%$ between the model and the experimental diffusivities is particularly low (Table 3). Furthermore, the $\mathrm{CO}_{2}$ diffusion coefficients in $[\mathrm{bmim}]\left[\mathrm{PF}_{6}\right]$ extrapolated from this correlation (taking a $\mathrm{CO}_{2}$ molar volume of $55 \mathrm{~cm}^{3} \mathrm{~mol}^{-1}$ [35]), were very close to those found by Shifflet and Yokozeki (2005), in the range 8-30\% for a temperature from 283.15 to $348.15 \mathrm{~K}$ [27].

On the one hand, the developed correlation presents a higher sensitivity to the temperature than the correlations listed Table 4, with a corresponding power of 1.63. This trend is in agreement with the observations of Morgan et al. (2005), which support a much larger temperature effect for diffusion in ionic liquids [33]. Besides, $\mathrm{Hou}$ and Baltus found that the diffusivity of $\mathrm{CO}_{2}$ in several ionic liquids varies with the temperature with a power of 3.3 [37]. On the other hand, diffusivity appears to vary inversely with the viscosity to the power of 0.702 . Therefore, the diffusivity in IL seems advantageously less sensitive to the viscosity than the other correlations currently used for traditional solvents. Scovazzo and his co-workers found similar values ( 0.66 for the imidazolium, 0.34-0.47 for phosphonium, and 0.59 for the ammonium based ILs) investigating the diffusion of ethylene, propylene, 1-butene, butadiene, methane and butane in several ionic liquids $[33,34,38]$.

All these results showed that to maximize the solute diffusivities, pure ILs or mixture with moderate viscosities and high molar volume (and high molar mass) should be developed. Indeed, a flexible structure combined to a high molar volume in order to increase voids within the ionic liquid, such as in phosphonium-based ionic liquids, allow to enhance solute diffusion $[33,48]$. 


\subsection{Assessment of ionic liquids for VOC removal}

\subsubsection{Introduction}

On the one hand, VOC partition coefficient measurements (part 3.1) undoubtedly emphasize the high potential of ionic liquids for hydrophobic VOC absorption with toluene partition coefficients from 200 to 1400 times lower than in water and with DCM partition coefficients from 14 to 50 times lower than in water. On the other hand, VOC diffusion coefficients in the selected ionic liquids (part 3.2) are from 18 to $90 \%$ lower than in traditional solvents such as water at $298 \mathrm{~K}$. Consequently, ionic liquids present a high absorption capacity for hydrophobic VOCs but their high viscosity might limit the mass-transfer rate in a gas-liquid contactor. Up to now, no experimental work has been performed using ionic liquids on a realistic gas-liquid contactor such as a counter-current packed column since the synthesis of massive amounts of ionic liquid is still challenging. However, the prediction of the hydrodynamics and mass-transfer rate in a packed column considering ionic liquids with moderate viscosities, such as $\left[\mathrm{AllylEt_{2 }} S\right]\left[\mathrm{NTf}_{2}\right]$ and $[\mathrm{Bmim}]\left[\mathrm{NTf}_{2}\right]$, is possible since theirs viscosities match the range covered by a few theories developed for viscous solvents.

\subsubsection{Theoretical background}

Table 6: Operating conditions simulated.

\begin{tabular}{|c|c|c|c|c|c|c|c|c|}
\hline $\begin{array}{l}D_{\text {col }} \\
\text { (m) }\end{array}$ & $\begin{array}{c}Z \\
\text { (m) }\end{array}$ & $\begin{array}{c}P \\
\text { (bar) }\end{array}$ & $\begin{array}{c}T \\
\text { (K) }\end{array}$ & $\begin{array}{c}F_{G} \\
\left(\mathrm{Nm}^{3} \mathrm{~h}^{-1}\right)\end{array}$ & $\left(\mathrm{m}^{3} \mathrm{~h}^{-1}\right)$ & $L / G$ & $\begin{array}{c}U_{S G} \\
\left(m^{-1}\right)\end{array}$ & $\begin{array}{c}U_{S L} \\
\left(\mathrm{~mm} \mathrm{~s}^{-1}\right)\end{array}$ \\
\hline 1.0 & 3.0 & 1 & 293 & 4000 & 11.0 & 3.07 & 1.52 & 3.89 \\
\hline
\end{tabular}

A fixed volume packed column (1.0 m of internal diameter and $3.0 \mathrm{~m}$ of height), consisting of $35 \mathrm{~mm}$ metal Pall rings, was simulated for the DCM and toluene absorption at counter-current in $\left[\right.$ AllylEt $\left.{ }_{2} \mathrm{~S}\right]\left[\mathrm{NTf}_{2}\right]$ and $[\mathrm{Bmim}]\left[\mathrm{NTf}_{2}\right]$. The same operating conditions (Table 6) and packing characteristics (Table S.12) than in the article of Biard et al. (2018) were considered in order to compare the results to DEHA and PDMS 50 [44]. The removal efficiency, defined by Eq. 9, was 
considered as the main performance indicator to assess the potential of the solvents along with the pressure drop:

$E f f=\frac{C_{G, i}-C_{G, o}}{C_{G, i}}$

Where $C_{G, i}$ and $C_{G, o}$ are the VOC concentrations in the gas at respectively the inlet and the outlet of the packing. Assuming isothermal liquid and gas plug flows at counter-current, the removal efficiency (Eff) obtained for a given column height $(Z$ in $\mathrm{m})$ is deduced by the following equation which does not depend on $C_{G, i}[41]$ :

$E f f=\frac{A\left(1-\exp \left((1-A) N T U_{O L}\right)\right)}{A-\exp \left((1-A) N T U_{O L}\right)}$ with $N T U_{O L}=\frac{Z}{H T U_{O L}}$ and $H T U_{O L}=\frac{F_{L}}{S_{c o l} \times K_{L} a^{\circ}}$

$N T U_{O L}$ (no unit) and $H T U_{O L}(\mathrm{~m})$ are respectively the overall Number and Height of a Transfer Unit in the liquid phase. $F_{L}$ is the liquid flow-rate $\left(\mathrm{m}^{3} \mathrm{~s}^{-1}\right), S_{c o l}$ is the column diameter $\left(\mathrm{m}^{2}\right)$ and $A$ is the absorption rate (dimensionless):

$A=\frac{F_{L}}{K_{H}{ }^{\prime} F_{G}}$ Eq. 11

$K_{L} a^{\circ}$ is the overall volumetric liquid-phase mass-transfer coefficient $\left(\mathrm{s}^{-1}\right)$ which is related to the gas and liquid-side coefficients $\left(k_{G}\right.$ and $k_{L}$ in $\left.\mathrm{m} \mathrm{s}^{-1}\right)$, the interfacial area $\left(a^{\circ}\right.$ in $\left.\mathrm{s}^{-1}\right)$ and the Henry's law constant $\left(K_{H}\right.$ in $\left.\mathrm{Pa} \mathrm{m}^{3} \mathrm{~mol}^{-1}\right)$ :

$\frac{1}{K_{L} a^{\circ}}=\frac{1}{k_{L} a^{\circ}}+\frac{R T}{K_{H} k_{G} a^{\circ}}$

The determination of the loading and flooding points, between which the systems should be operated, of the interfacial area $\left(a^{\circ}\right)$ and of the liquid hold-up $\left(h_{L}\right)$ is necessary prior to calculate $K_{L} a^{\circ}$. The dedicated correlations of Billet-Schultes, which have been developed with solvents having kinematic viscosities $\left(\mu_{L} / \rho_{L}\right)$ up to 100 or $142 \times 10^{-6} \mathrm{~m}^{2} \mathrm{~s}^{-1}$ (depending on the determined variable), include $\left[\right.$ AllylEt $\left.{ }_{2} \mathrm{~S}\right]\left[\mathrm{NTf}_{2}\right]$ and $[\mathrm{Bmim}]\left[\mathrm{NTf}_{2}\right][44,49-52]$. For the determination of the mass-transfer coefficients and of the interfacial area, both the correlations of Billet-Schultes (B-S) and the recent 
correlation of Song-Seibert-Rochelle (S-S-R), specially designed for viscous solvents up to $70 \mathrm{mPa}$, were essentially considered [52-55].

\subsubsection{Simulation of the hydrodynamics}

Owing to similar viscosities, surface tensions and densities (Table 5), the hydrodynamics parameters simulated for the two ILs were particularly close (Table 7). The loading $\left(U_{S G, \mid l o}\right)$ and flooding $\left(U_{S G, f l}\right)$ velocities are advantageously higher in the two considered ionic liquids (respectively around 1.3 and $2.4 \mathrm{~m} \mathrm{~s}^{-1}$ ) than in DEHA and PDMS 50, even with similar viscosities. This behavior is supported by the fact that the high viscosity of these two ILs is counterbalanced by a high density (around 50\% higher than PDMS 50 and DEHA). A liquid hold-up $\left(h_{L}\right)$ of nearly $14-15 \%$, similar to those simulated for DEHA and PDMS 50, were calculated. Finally, an acceptable pressure drop of nearly $400 \mathrm{~Pa} \mathrm{~m}^{-1}$, around $40 \%$ higher than in water, was simulated [44].

In agreement with the results published earlier considering DEHA and PDMS 50 [44], the interfacial areas simulated using the B-S theory were particularly large $\left(\approx 340 \mathrm{~m}^{2} \mathrm{~m}^{-3}\right)$ and $244 \%$ higher than the packing specific surface $\left(A_{p}=139 \mathrm{~m}^{2} \mathrm{~m}^{-3}\right)$ which seems unlikely. Such a high discrepancy is not surprising since this correlation was essentially developed with water-like systems with kinematic viscosities in the range $0.14-1.66 \mathrm{~m}^{2} \mathrm{~s}^{-1}$, which is far to include heavy solvents $[52,53]$. Recently, Song-Seibert-Rochelle proposed a new correlation to calculate $a^{\circ}$ using random and structured packings for viscous solvents up to $70 \mathrm{mPa}$ s $[54,56]$ :

$\frac{a^{\circ}}{A_{p}}=C \times\left(\frac{\rho_{L}}{\sigma} g^{1 / 2} A_{p}{ }^{-3 / 2} U_{S L}\right)^{0.138}$ Eq. 13

With $C=1.15 \times 1 \times\left(1.34-0.26 \frac{A_{p}}{250}\right)$ for a metal random packing operated in the loading zone. This correlation does not depend on the viscosity since the authors concluded that it does not have a significant effect on $a^{\circ}$. It leads to a value of $a^{\circ} 37 \%$ higher than $A_{p}$, which is more realistic than using the B-S theory. The experimental observations of S-S-R support the fact that $a^{\circ}$ might be higher than 
$A_{p}$ since the liquid can flow as large rivulets, droplets and waves and practically stagnant liquid might be present within the column [56].

The interfacial area found using the S-S-R theory was compared to the values deduced from the Piché et al. and Onda correlations, which were both developed with water-like systems $[44,57,58]$. These two theories predicted realistic but low interfacial areas, which do not support the observations of S-S-R. Consequently, only the values of $a^{\circ}$ deduced from Eq. 13 was considered to calculate the overall volumetric liquid-phase mass-transfer coefficient from Eq. 12 in the section 3.3.4.

Table 7: Determination of the loading and flooding points, liquid hold-up, linear pressure drop by the B-S theory and of the interfacial area by several theories.

\begin{tabular}{|c|c|c|c|c|c|c|c|c|c|}
\hline \multirow[t]{2}{*}{ Solvent } & \multirow{2}{*}{$\begin{array}{l}U_{S G, l o} \\
\left(\mathrm{~m} \mathrm{~s}^{-1}\right)\end{array}$} & \multirow{2}{*}{$\begin{array}{l}U_{S G, f I} \\
\left(\mathrm{~m} \mathrm{~s}^{-1}\right)\end{array}$} & \multirow[t]{2}{*}{$U_{S G} / U_{S G, f l}$} & \multirow{2}{*}{$\begin{array}{c}h_{L} \\
(\%)\end{array}$} & \multirow{2}{*}{$\begin{array}{c}\Delta P / z \\
\left(\mathrm{~Pa} \mathrm{\textrm {m } ^ { - 1 }}\right)\end{array}$} & \multicolumn{4}{|c|}{$a^{0}\left(\mathrm{~m}^{2} \mathrm{~m}^{-3}\right)$} \\
\hline & & & & & & Piché et al. & B-S & Onda & S-S-R \\
\hline DEHA & 1.19 & 2.14 & 0.71 & 10.2 & 361 & 64.6 & 203 & 105 & 180 \\
\hline PDMS 50 & 1.15 & 2.03 & 0.75 & 15.8 & 418 & 61.0 & 371 & 117 & 192 \\
\hline$\left[\right.$ AllylEt $\left.{ }_{2} \mathrm{~S}\right]\left[\mathrm{NTf}_{2}\right]$ & 1.30 & 2.40 & 0.63 & 14.2 & 394 & 61.0 & 337 & 103 & 191 \\
\hline$[$ Bmim $]\left[\mathrm{NTf}_{2}\right]$ & 1.30 & 2.38 & 0.64 & 14.9 & 400 & 59.7 & 343 & 102 & 191 \\
\hline
\end{tabular}

\subsubsection{Simulation of the mass-transfer and calculation of the removal efficiency}

Both the S-S-R and B-S theories were considered to calculate the liquid and gas-film mass-transfer coefficients $\left(k_{L}\right.$ and $\left.k_{G}\right)$. Since the gas-film mass-transfer coefficients is not affected by the liquid properties, realistic and rather close values of $k_{G}$, in the range $2.3-4.3 \times 10^{-2} \mathrm{~m} \mathrm{~s}^{-1}$, were deduced considering both theories (Tables 8 and 9). The values of $k_{G}$ determined with the B-S correlation were from 50 to $60 \%$ higher than those determined with the S-S-R correlation. This slight discrepancy has a low influence on the removal efficiency calculation since it has a low sensitivity to $k_{G}$ (part 3.3.5).

However, the two theories present high discrepancies for the calculation of $k_{L}$. Indeed, the B-S theory predicted values of $k_{L}$ around 8 times higher than the S-S-R theory (Tables 8 and 9 ). On the one hand, 
according to the B-S theory, $k_{L}$ does not depend directly on the viscosity and surface tension but depends on them indirectly through their influence on the diffusivity (with a power of $1 / 2$ according to the penetration theory) and liquid hold-up (with a power of $-1 / 2$ ) which varies only from a factor 3 between heavy solvents and water (Table 7) [1]. On the other hand, the S-S-R theory predicts a total dependence of $k_{L}$ on the viscosity with a power of -0.75 , of which -0.35 is from the indirect influence through diffusivity, and -0.4 is from the direct influence through liquid turbulence [56]. Thus, the higher sensitivity of the S-S-R correlation to the viscosity leads to very low and probably underestimated values of $k_{L}$. Thus, the experimental values of $K_{L} a^{\circ}$ determined by Guillerm et al. (2016) for the toluene absorption in PDMS 50 using two different packings (one random packing: IMTP and one structured packing: Flexipac) were compared to the values deduced using the correlations of S-S-R [59]. The experimental values were in average 17\% (IMTP packing) and 53\% (Flexipac packing) higher, confirming the tendency of the correlations of S-S-R to underestimate $k_{L}$ and $K_{L} a^{\circ}$ (Fig. S9). Thus, as an alternative, a combination of the S-S-R theory, to calculate $a^{\circ}$, and of the B-S theory, to calculate both $k_{L}$ and $k_{G}$, was considered for the simulation of the VOCs masstransfer in $\left[\right.$ AllylEt $\left.{ }_{2} \mathrm{~S}\right]\left[\mathrm{NTf}_{2}\right]$ and $[\mathrm{Bmim}]\left[\mathrm{NTf}_{2}\right]$ (Tables 8 and 9). This combination leads to $K_{L} a^{\circ}$ values around $80 \%$ higher than those deduced considering only the S-S-R theory, which might be rather optimistic regarding the relative difference between the experimental results of Guillerm et al. (2016) and the correlations of S-S-R [59]. Thus, the real values of $K_{L} a^{\circ}$ (and of $H T U$ and Eff) should be included with a good confidence level between these two predictions. 
Table 8: Mass-transfer coefficients, HTU and removal efficiencies in [AllylEt $\left.{ }_{2} S\right]\left[N T f_{2}\right.$ ] (First case : $k_{L}$ and $k_{G}$ are deduced from the B-S theory and $a^{\circ}$ is deduced from the S-S-R theory; second case : $k_{L}$ $k_{G}$ and $a^{\circ}$ are deduced from only the S-S-R theory).

\begin{tabular}{|c|c|c|c|c|c|c|c|c|c|c|}
\hline \multirow{3}{*}{ VOC } & \multicolumn{5}{|c|}{$\begin{array}{l}\text { B-S theory for } k_{L} \text { and } k_{G}, \\
\text { S-S-R theory for } a^{\circ}\end{array}$} & \multicolumn{5}{|c|}{ S-S-R theory for $k_{L}, k_{G}$ and $a^{\circ}$} \\
\hline & $10^{5} \times k_{L}$ & $10^{2} \times k_{G}$ & $10^{3} \times K_{L} a^{\circ}$ & HTU & Eff & $10^{5} \times k_{L}$ & $10^{2} \times k_{G}$ & $10^{3} \times K_{L} a^{\circ}$ & HTU & Eff \\
\hline & $\mathrm{m} \mathrm{s}^{-1}$ & $\mathrm{~m} \mathrm{~s}^{-1}$ & $s^{-1}$ & $\mathrm{~m}$ & $\%$ & $\mathrm{~m} \mathrm{~s}^{-1}$ & $\mathrm{~m} \mathrm{~s}^{-1}$ & $s^{-1}$ & $\mathrm{~m}$ & $\%$ \\
\hline Toluene & 1.17 & 3.45 & 1.15 & 3.38 & 99.6 & 0.154 & 2.26 & 0.247 & 15.72 & 71.9 \\
\hline DCM & 1.89 & 4.25 & 3.31 & 1.17 & 42.8 & 0.249 & 2.64 & 0.467 & 8.33 & 14.5 \\
\hline
\end{tabular}

Table 9: Mass-transfer coefficients, HTU and removal efficiencies in [bmim] [NTf $f_{2}$ (First case : $\boldsymbol{k}_{L}$ and $k_{G}$ are deduced from the $B-S$ theory and $a^{\circ}$ is deduced from the S-S-R theory; second case : $k_{L} k_{G}$ and $a^{\circ}$ are deduced from only the S-S-R theory).

\begin{tabular}{|c|c|c|c|c|c|c|c|c|c|c|}
\hline \multirow{3}{*}{ VOC } & \multicolumn{5}{|c|}{$\begin{array}{l}\text { B-S theory for } k_{L} \text { and } k_{G} \text {, } \\
\text { S-S-R theory for } a^{\circ}\end{array}$} & \multicolumn{5}{|c|}{ S-S-R theory for $k_{L}, k_{G}$ and $a^{\circ}$} \\
\hline & $10^{5} \times k_{L}$ & $10^{2} \times k_{G}$ & $10^{3} \times K_{L} a^{\circ}$ & HTU & Eff & $10^{5} \times k_{L}$ & $10^{2} \times k_{G}$ & $10^{3} \times K_{L} a^{\circ}$ & HTU & Eff \\
\hline & $\mathrm{m} \mathrm{s}^{-1}$ & $\mathrm{~m} \mathrm{~s}^{-1}$ & $s^{-1}$ & $\mathrm{~m}$ & $\%$ & $\mathrm{~m} \mathrm{~s}^{-1}$ & $\mathrm{~m} \mathrm{~s}^{-1}$ & $s^{-1}$ & $\mathrm{~m}$ & $\%$ \\
\hline Toluene & 1.09 & 3.46 & 1.36 & 2.87 & 97.6 & 0.139 & 2.26 & 0.240 & 16.18 & 52.7 \\
\hline DCM & 1.76 & 4.27 & 3.09 & 1.26 & 43.8 & 0.224 & 2.64 & 0.420 & 9.26 & 14.0 \\
\hline
\end{tabular}

From the $K_{L} a^{\circ}$ values, the heights of a transfer unit and the removal efficiencies were calculated using

Eq. 10. Fig. S10 shows a comparison between the experimental values of Eff measured by Guillerm et al. (2016) and those deduced considering only the S-S-R theory. The experimental values were in average 11\% (IMTP packing) and 23\% (Flexipac packing) higher than the theoretical one. The results published previously for DEHA and PDMS 50 were updated with the S-S-R theory, with interfacial areas of 180 and $192 \mathrm{~m}^{2} \mathrm{~m}^{-3}$, respectively (Table 7) [44]. The resulting removal efficiencies are provided Fig. 2 for comparison with the two simulated ILs. The toluene removal efficiency was higher in DEHA than in PDMS 50 and the two ILS and should be in the range $99.6 \%-99.97 \%$ depending on the considered correlations used to determine the mass-transfer coefficients. This result is mainly due to a lower toluene partition coefficient in DEHA (0.76 Pa m $\left.\mathrm{mol}^{-1}\right)$ than in the other solvents and with a lower extent to a lower viscosity leading to higher diffusion coefficients. PDMS 50 and [AllylEt $\left.{ }_{2} \mathrm{~S}\right]\left[\mathrm{NTf}_{2}\right]$ exhibited similar interesting performances whatever the considered theory $(99.6 \%$ 
with the S-S-R/B-S theories combination, $72 \%$ with the S-S-R theory). Eff in [bmim] $\left[\mathrm{NTf}_{2}\right]$ was lower than in the other solvents owing to a higher partition coefficient $\left(1.44 \mathrm{~Pa} \mathrm{~m}^{3} \mathrm{~mol}^{-1}\right)$ and a lower diffusion coefficient than in PDMS 50, but it remains competitive $(97.6 \%$ with the S-S-R/B-S combination, 53\% with the S-S-R theory). The DCM simulated removal efficiencies were more disappointing, in agreement with significantly higher partition coefficients. Indeed, whatever the theory considered, the silicon oil and both ILs exhibited removal efficiencies lower than $40 \%$, emphasizing the higher potential of DEHA to remove a large panel of VOCs [1].

(a)

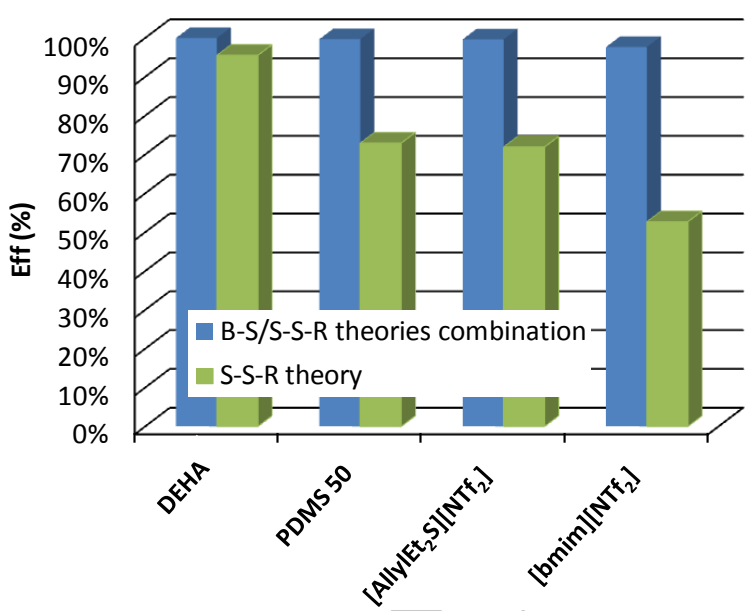

(b)

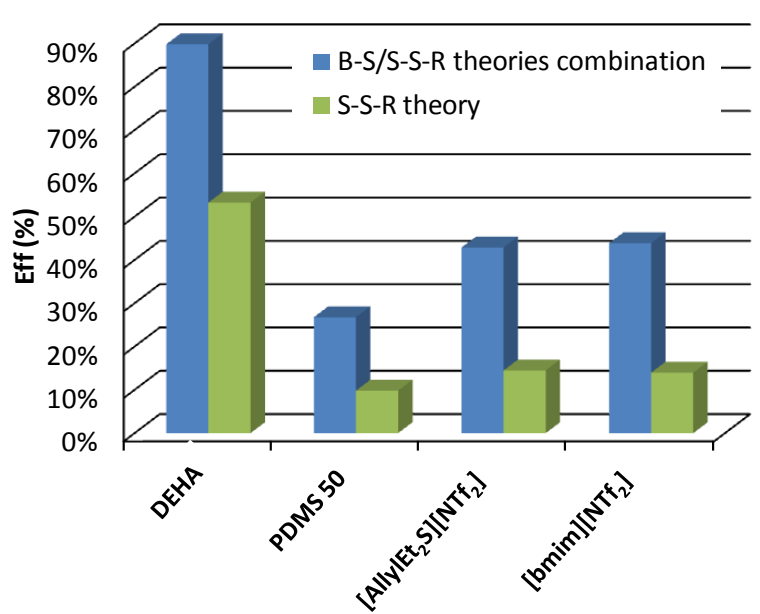

Figure 2. Toluene (a) and DCM (b) removal efficiencies simulated in various heavy solvents according to the operating conditions selected (Table 6). Blue bars : $k_{L}$ and $k_{G}$ are deduced from the $B-S$ theory and $a^{\circ}$ is deduced from the S-S-R theory; green bars : $k_{L} k_{G}$ and $a^{\circ}$ are deduced from only the S-S-R theory.

\subsubsection{Sensitivity analysis}

Fig. 2 emphasizes a rather high discrepancy between the two considered theories. Nonetheless, it should allow to assess the potential of a heavy solvents to remove a given VOC with a rather good confidence level since Eff might be more affected by $K_{H}$ than by $K_{L} a^{\circ}$ (and consequently by the liquidphase diffusion coefficient). To confirm this, a sensitivity analysis based on the determination of the elasticity index (EI) was carried out [60]. The selected output was the removal efficiency and the 
inputs were $k_{L}, k_{G}, K_{L} a^{\circ}$ and $K_{H}$. El were calculated for the four studied VOC/ILs systems simulated. The results confirm undoubtedly the low sensitivity of Eff to $k_{G}$, the mass-transfer resistance being predominantly located in the liquid phase. The sensitivity to $k_{L}$ was moderate, especially for toluene with $E$ I lower than 0.3 , which means that an uncertainty on $k_{L}$ of $10 \%$ will affect Eff by less than $3 \%$. Then, since $k_{L}$ increases with $D_{L}$ at the power of 0.5 , the El values for $D_{L}$ are 2.6 times lower than the one for $k_{L}$, showing a limited sensitivity of $k_{L}$ to $D_{L}$. The sensitivity to $a^{\circ}\left(K_{L} a^{\circ}\right)$ was higher but this parameter was determined with a better confidence level than $k_{L}$, whose the value can vary on several orders of magnitude ( 0.1 to $50 \times 10^{-4} \mathrm{~m} \mathrm{~s}^{-1}$ for $k_{L}$ for example). Finally, the results confirmed the higher sensitivity of Eff to the partition coefficient $K_{H}$, especially for DCM. Since $K_{H}$ values were determined accurately, it confirms that the assessment of different solvents through the determination of the partition coefficient is rather pertinent and that the simulations carried out allows comparing different solvents with a good confidence level.

Figure 3. Elasticity index calculated for toluene (a) and DCM (b). Output: removal efficiency, Inputs : $k_{L} k_{G}, K_{L} a^{\circ}$ and Eff. The BS/S-S-R theories combination was considered.

(a)

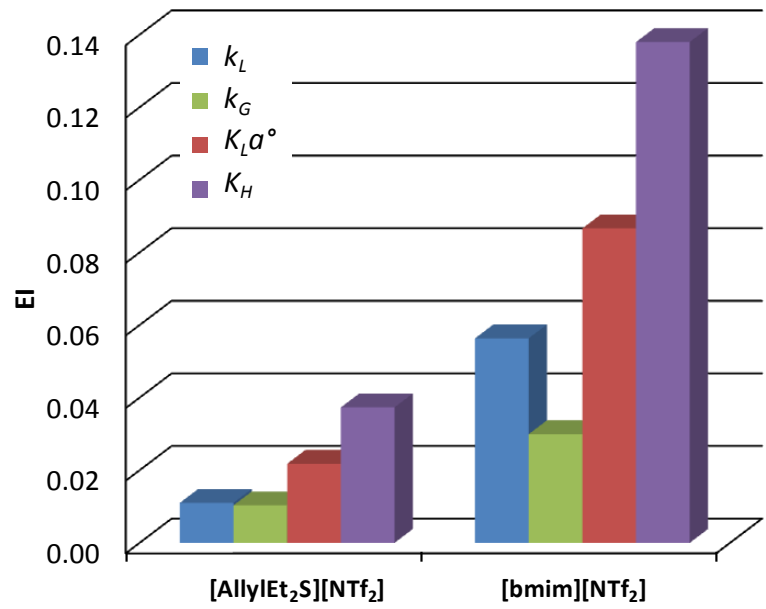

(b) Dichloromethane

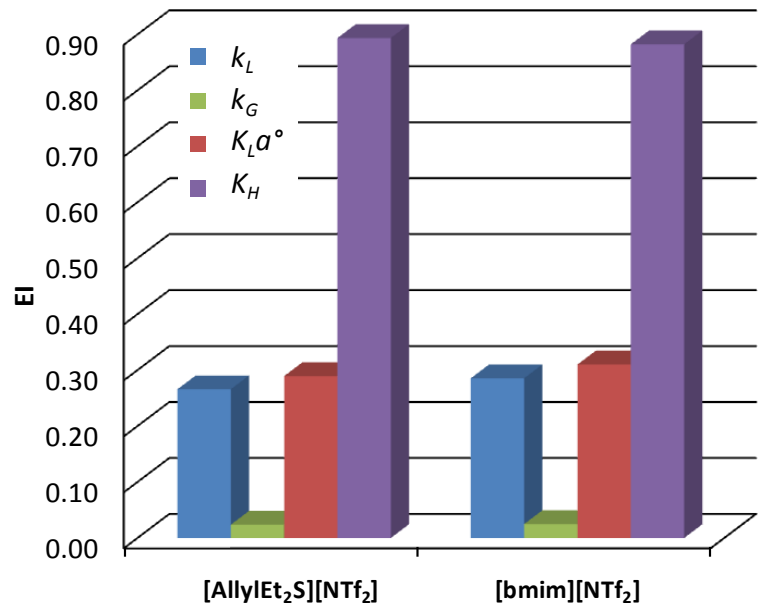




\section{Conclusion}

Partition coefficient of toluene and DCM in 23 hydrophobic ILs were measured by the static headspace method at $298 \mathrm{~K}$. The results clearly demonstrated the high affinity of ionic liquids for hydrophobic VOCs, especially toluene. The diffusion coefficients at infinite dilution were also measured using a thermogravimetric microbalance for four selected ionic liquids. These diffusion coefficients ranged between 1 and $4 \times 10^{-11} \mathrm{~m}^{2} \mathrm{~s}^{-1}$ for temperature in the range $278-308 \mathrm{~K}$ and were from 18 to 90 times lower than in water. The diffusion coefficients were satisfactorily correlated to the temperature, the solvent viscosity and both solvent and solute molar volumes, with an average relative error of $4.2 \%$. The correlation highlighted advantageously a stronger dependence of the diffusion coefficient to the temperature and a lower dependence to the solvent viscosity than the conventional correlations. The hydrodynamics of a counter-current packed column fed with [bmim] $\left[\mathrm{NTf}_{2}\right]$ and $\left[\mathrm{AllylEt}_{2} \mathrm{~S}\right]\left[\mathrm{NTf}_{2}\right]$ at $293 \mathrm{~K}$ was simulated considering the Billet-Schultes theory. Realistic and worthwhile loading and flooding velocities (respectively around 1.3 and $2.4 \mathrm{~m} \mathrm{~s}^{-1}$ ) were determined despite the high IL viscosity, which was partly compensated by their high density. The linear pressure drop calculated, around $400 \mathrm{~Pa} \mathrm{~m}^{-1}$, was competitive and comparable to those simulated with DEHA and PDMS 50. Then, the overall liquid-side mass-transfer coefficients were calculated considering both the Billet-Schultes and Song-Seibert-Rochelle correlations to finally determine the removal efficiency in a $3 \mathrm{~m}$ height column. The S-S-T theory predicted reliable interfacial areas, but low and unlikely liquid-film mass-transfer coefficients (in the range 0.15$0.25 \times 10^{-5} \mathrm{~m} \mathrm{~s}^{-1}$ ), whereas the B-S theory predicted reliable values of the liquid-film mass-transfer coefficient (in the range 1.1-1.9 $\times 10^{-5} \mathrm{~m} \mathrm{~s}^{-1}$ ) but very high and unlikely values of the interfacial area (2.45 times higher than the packing specific surface area). Thus, a combination of these two theories was proposed to determine the overall liquid-side mass-transfer coefficients. The results emphasized the good potential of the two ILs for the toluene absorption. However, the DCM removal efficiencies were quite disappointing, between $14 \%$ and $44 \%$, higher than in PDMS 50 but significantly lower than 
in DEHA (53 to 90\%), a solvent which guarantees a better affinity for VOCs than silicon oils and the synthesized ionic liquids [1].

New and more effective ionic liquids with large structure and with limited viscosities to enhance solute diffusion might be synthesized in the future, trying to optimize the affinity for a large panel of VOCs. Molecular simulations can provide valuable information to guide the design of such dedicated ionic liquids [61].

\section{Funding source}

The authors want to thank the ANR for the founding support (ANR 12 BLAN 007 01).

\section{Acknowledgments}

The authors are very grateful to Sylvain Giraudet for his support using the IGA 003 and to Alicia Janeiro, Mickael Badin and Tiphaine Blanchard for their help. The authors are also very grateful to Gary Rochelle (University of Texas in Austin) for his kind answers to our questions. 


\section{Glossary}

$a^{\circ}$ : interfacial area relative to the packing volume $\left(\mathrm{m}^{2} \mathrm{~m}^{-3}\right)$

$A$ : absorption rate (dimensionless)

$A_{i}$ : abnormality factor to account of system non-idealities (Arnold correlation)

$A_{p}$ : packing specific surface area $\left(\mathrm{m}^{2} \mathrm{~m}^{-3}\right)$

$A R$ : affinity ratio defined as $K_{H}$ in water divided by $K_{H}$ in IL

B-S: Billet-Schultes

C: Constant (Scheibel correlation or Eq.12)

$C_{L}$ or $\left(C_{G}\right)$ : VOC concentration in the liquid phase (gas phase, $\mathrm{mol} \mathrm{m}^{-3}$ or $\mathrm{mol} \mathrm{L}^{-1}$ )

$d_{p}$ : packing size $(\mathrm{m})$

DCM: dichloromethane

$D_{c o l}:$ column diameter $(\mathrm{m})$

$D_{i}$ or $D_{L}$ : diffusion coefficient at infinite dilution of a solute $i$ in the liquid phase $\left(\mathrm{m}^{2} \mathrm{~s}^{-1}\right)$

$D_{G}$ : diffusion coefficient at infinite dilution of a solute in the gas phase (liquid phase) $\left(\mathrm{m}^{2} \mathrm{~s}^{-1}\right)$

Eff: removal efficiency

El: elasticity index

F: flow-rate $\left(\mathrm{m}^{3} \mathrm{~s}^{-1}\right.$ or $L \mathrm{~s}^{-1}$, often expressed in the normal conditions of temperature and pressure for a gas)

$g$ : acceleration of gravity $\left(9.81 \mathrm{~m} \mathrm{~s}^{-2}\right)$ 
$h_{L}$ : liquid hold-up (dimensionless)

$H T U_{O L}$ : overall height of a transfer unit in the liquid phase $(\mathrm{m})$

$K_{H}$ : partition coefficient (Henry's law coefficient in $\mathrm{Pa} \mathrm{m}^{3} \mathrm{~mol}^{-1}$ )

$K_{H}{ }^{\prime}$ : dimensionless partition coefficient (Henry's law coefficient)

$k_{G}$ : gas-film mass-transfer coefficient $\left(\mathrm{m} \mathrm{s}^{-1}\right)$

$k_{L}$ : liquid-film mass-transfer coefficient $\left(\mathrm{m} \mathrm{s}^{-1}\right)$

$K_{L} a^{\circ}:$ overall volumetric liquid-side mass-transfer coefficient $\left(\mathrm{s}^{-1}\right)$

$L$ : initial liquid height $(\mathrm{m})$

$L / G$ : liquid-to-gas mass flow-rate ratio (dimensionless)

$M_{i}\left(M_{L}\right):$ molecular weight of a solute i (or solvent $\left.\mathrm{L}\right)\left(\mathrm{g} \mathrm{mol}^{-1}\right.$ )

$N T U_{O L}$ : overall number of transfer units in the liquid phase

$P$ : absolute pressure $(\mathrm{Pa})$

$P a:$ parachor $\left(\mathrm{g}^{1 / 4} \mathrm{~cm}^{3} \mathrm{~mol}^{-1} \mathrm{~s}^{-1 / 2}\right)$

$R$ : ideal gas constant $\left(8.314 \mathrm{~J} \mathrm{~mol}^{-1} \mathrm{~K}^{-1}\right)$

$R E$ : relative error

$R S D$ : relative standard deviation

$R_{L}:$ relative mass-transfer resistance in the liquid phase (\%)

$S_{c o l}:$ column section $\left(\mathrm{m}^{2}\right)$

S-S-R: Song-Seibert-Rochelle 
$T$ : temperature of the contactor $(\mathrm{K})$

$t$ : time (s)

$U:$ fluid velocity $\left(\mathrm{m} \mathrm{s}^{-1}\right)$

$V_{m}$ : solute or solvent molar volume $\left(\mathrm{cm}^{3} \mathrm{~mol}^{-1}\right)$

VOC: volatile organic compound

$Z$ : contactor height $(\mathrm{m})$

$z$ : vertical coordinate $(\mathrm{m})$

\section{Greek letters:}

$\alpha$ : Association factor (Wilke-Chang correlation)

$\varepsilon$ : void fraction (\%)

$\Delta P / z$ : linear pressure drop $(\mathrm{Pa})$

$\mu$ : dynamic viscosity (Pa s)

$\sigma$. surface tension $\left(\mathrm{N} \mathrm{m}^{-1}\right)$

$\rho:$ density $\left(\mathrm{kg} \mathrm{m}^{-3}\right)$

\section{Subscripts:}

fl: at the flooding point

G: relative to the gas 
$\mathrm{i}$ : at the packing inlet

$\mathrm{L}$ : relative to the liquid (solvent)

lo: at the loading point

O: overall

o: at the packing outlet

$\mathrm{p}$ : relative to the packing

S: superficial (velocity)

s: final

VOC: relative to the VOC (solute)

0: initial 


\section{References list}

[1] P.-F. Biard, A. Coudon, A. Couvert, S. Giraudet, A simple and timesaving method for the masstransfer assessment of solvents used in physical absorption, Chem. Eng. J. 290 (2016) 302-311.

[2] G. Darracq, A. Couvert, C. Couriol, A. Amrane, P. Le Cloirec, Integrated process for hydrophobic VOC treatment-solvent choice, Can. J. Chem. Eng. 88 (2010) 655-660.

[3] G. Darracq, A. Couvert, C. Couriol, A. Amrane, D. Thomas, E. Dumont, Y. Andres, P. Le Cloirec, Silicone oil: An effective absorbent for the removal of hydrophobic volatile organic compounds, Journal of Chemical Technology \& Biotechnology 85 (2010) 309-313.

[4] R. Hadjoudj, H. Monnier, C. Roizard, F. Lapicque, Absorption of Chlorinated VOCs in High-Boiling Solvents: Determination of Henry's Law Constants and Infinite Dilution Activity Coefficients, Ind. Eng. Chem. Res. 43 (2004) 2238-2246.

[5] F. Heymes, P. Manno-Demoustier, F. Charbit, J.L. Fanlo, P. Moulin, A new efficient absorption liquid to treat exhaust air loaded with toluene, Chem. Eng. J. 115 (2006) 225-231.

[6] D. Bourgois, D. Thomas, J.L. Fanlo, J. Vanderschuren, Solubilities at high dilution of toluene, ethylbenzene, 1, 2, 4-trimethylbenzene, and hexane in di-2-ethylhexyl, diisoheptyl, and diisononyl phthalates, Journal of Chemical Engineering Data 51 (2006) 1212-1215.

[7] D. Bourgois, J. Vanderschuren, D. Thomas, Study of mass transfer of VOCs into viscous solvents in a pilot-scale cables-bundle scrubber, Chem. Eng. J. 145 (2009) 446-452.

[8] S. Guihéneuf, A.S.R. Castillo, L. Paquin, P.-F. Biard, A. Couvert, A. Amrane, Absorption of Hydrophobic Volatile Organic Compounds in Ionic Liquids and Their Biodegradation in Multiphase Systems, Production of Biofuels and Chemicals with lonic Liquids, Springer2014, pp. 305-337.

[9] A.S. Rodriguez Castillo, S. Guihéneuf, P.-F. Biard, L. Paquin, A. Amrane, A. Couvert, Physicochemical properties of some hydrophobic room-temperature ionic liquids applied to volatile organic compounds biodegradation processes, Journal of Chemical Technology \& Biotechnology 93 (2018) 215-223. 
[10] G. Quijano, A. Couvert, A. Amrane, G. Darracq, C. Couriol, P. Le Cloirec, L. Paquin, D. Carrié, Absorption and Biodegradation of Hydrophobic Volatile Organic Compounds in Ionic Liquids, Water, Air, \& Soil Pollution 224 (2013) 1528, 1521-1529.

[11] A.S. Rodriguez Castillo, S. Guihéneuf, R. Le Guével, P.-F. Biard, L. Paquin, A. Amrane, A. Couvert, Synthesis and toxicity evaluation of hydrophobic ionic liquids for volatile organic compounds biodegradation in a two-phase partitioning bioreactor, J. Hazard. Mater. 307 (2016) 221-230.

[12] T.-V.-N. Nguyen, A.S. Rodriguez Castillo, S. Guihéneuf, P.-F. Biard, L. Paquin, A. Amrane, A. Couvert, Toluene degradation in a two-phase partitioning bioreactor involving a hydrophobic ionic liquid as a non-aqueous phase liquid, International Biodeterioration \& Biodegradation 117 (2017) 3138.

[13] A.S. Rodriguez Castillo, S. Guihéneuf, P.-F. Biard, L. Paquin, A. Amrane, A. Couvert, Impact of Activated Sludge Acclimation on the Biodegradation of Toluene Absorbed in a Hydrophobic Ionic Liquid, International Journal of Environmental Science and Technology 15 (2018) 621-630.

[14] M. Guillerm, A. Couvert, A. Amrane, É. Dumont, E. Norrant, N. Lesage, C. Juery, Characterization and selection of PDMS solvents for the absorption and biodegradation of hydrophobic VOCs, J. Chem. Technol. Biotechnol. 95 (2015) 1923-1927.

[15] T. Welton, Room-temperature ionic liquids: solvents for synthesis and catalysis. 2., Chemical Reviews 99 (1999) 2071-2083.

[16] J.S. Wilkes, A short history of ionic liquids-from molten salts to neoteric solvents, Green Chemistry 4 (2002) 73-80.

[17] J.S. Wilkes, J.A. Levisky, R.A. Wilson, C.L. Hussey, Dialkylimidazolium chloroaluminate melts: a new class of room-temperature ionic liquids for electrochemistry, spectroscopy and synthesis, Inorg. Chem. 237 (1982) 1263-1264.

[18] C. Chiappe, D. Pieraccini, Ionic liquids: solvent properties and organic reactivity, Journal of Physical Organic Chemistry 18 (2005) 275-297. 
[19] J.G. Huddleston, A.E. Visser, W.M. Reichert, H.D. Willauer, G.a. Broker, R.D. Rogers, Characterization and comparison of hydrophilic and hydrophobic room temperature ionic liquids incorporating the imidazolium cation, Green Chemistry 3 (2001) 156-164.

[20] A. Maiti, R.D. Rogers, A correlation-based predictor for pair-association in ionic liquids., Physical Chemistry Chemical Physics : PCCP 13 (2011) 12138-12145.

[21] I.A. Shkrob, J.F. Wishart, Charge trapping in imidazolium ionic liquids., The Journal of Physical Chemistry B 113 (2009) 5582-5592.

[22] H. Weingärtner, Understanding ionic liquids at the molecular level: facts, problems, and controversies., Angewandte Chemie 47 (2008) 654-670.

[23] G. Quijano, A. Couvert, A. Amrane, G. Darracq, C. Couriol, P. Le Cloirec, L. Paquin, D. Carrié, Potential of ionic liquids for $\mathrm{VOC}$ absorption and biodegradation in multiphase systems, Chem. Eng. Sci. 66 (2011) 2707-2712.

[24] M.B. Shiflett, B.A. Elliott, A.M.S. Niehaus, A. Yokozeki, Separation of $\mathrm{N}_{2} \mathrm{O}$ and $\mathrm{CO}_{2}$ using roomtemperature ionic liquid [bmim][Ac], Separation Science and Technology 47 (2012) 411-421.

[25] M.B. Shiflett, A.M.S. Niehaus, B.A. Elliott, A. Yokozeki, Phase Behavior of $\mathrm{N}_{2} \mathrm{O}$ and $\mathrm{CO}_{2}$ in RoomTemperature Ionic Liquids $[\mathrm{bmim}]\left[\mathrm{Tf}_{2} \mathrm{~N}\right],[\mathrm{bmim}]\left[\mathrm{BF}_{4}\right],[\mathrm{bmim}]\left[\mathrm{N}(\mathrm{CN})_{2}\right],[\mathrm{bmim}][\mathrm{Ac}]$, [eam] $\left[\mathrm{NO}_{3}\right]$, and [bmim][SCN], International Journal of Thermophysics 33 (2012) 412-436.

[26] M.B. Shiflett, A.M.S. Niehaus, A. Yokozeki, Separation of $\mathrm{N}_{2} \mathrm{O}$ and $\mathrm{CO}_{2}$ using room-temperature ionic liquid [bmim] $\left[\mathrm{BF}_{4}\right]$, The Journal of Physical Chemistry B 115 (2011) 3478-3487.

[27] M.B. Shiflett, A. Yokozeki, Solubilities and Diffusivities of Carbon Dioxide in Ionic Liquids: [bmim] $\left[\mathrm{PF}_{6}\right]$ and $[\mathrm{bmim}]\left[\mathrm{BF}_{4}\right]$, Ind. Eng. Chem. Res. 44 (2005) 4453-4464.

[28] M.B. Shiflett, A. Yokozeki, Solubility of $\mathrm{CO}_{2}$ in Room Temperature lonic Liquid [hmim] $\left[\mathrm{Tf}_{2} \mathrm{~N}\right]$, The Journal of Physical Chemistry B 111 (2007) 2070-2074.

[29] A. Yokozeki, M.B. Shiflett, C.P. Junk, L.M. Grieco, T. Foo, Physical and Chemical Absorptions of Carbon Dioxide in Room-Temperature Ionic Liquids, The Journal of Physical Chemistry B 112 (2008) 16654-16663. 
[30] M.B. Shiflett, M.A. Harmer, C.P. Junk, A. Yokozeki, Solubility and diffusivity of 1,1,1,2tetrafluoroethane in room-temperature ionic liquids, Fluid Phase Equilibria 242 (2006) 220-232.

[31] M.B. Shiflett, M.A. Harmer, C.P. Junk, A. Yokozeki, Solubility and Diffusivity of Difluoromethane in Room-Temperature lonic Liquids, J. Chem. Eng. Data 51 (2006) 483-495.

[32] M.B. Shiflett, A. Yokozeki, Solubility and diffusivity of hydrofluorocarbons in room-temperature ionic liquids, AIChE J. 52 (2006) 1205-1219.

[33] D. Morgan, L. Ferguson, P. Scovazzo, Diffusivities of Gases in Room-Temperature Ionic Liquids: Data and Correlations Obtained Using a Lag-Time Technique, Ind. Eng. Chem. Res. 44 (2005) 48154823.

[34] L. Ferguson, P. Scovazzo, Solubility, Diffusivity, and Permeability of Gases in Phosphonium-Based Room Temperature lonic Liquids: Data and Correlations, Ind. Eng. Chem. Res. 46 (2007) 1369-1374.

[35] D. Camper, C. Becker, C. Koval, R. Noble, Diffusion and Solubility Measurements in Room Temperature Ionic Liquids, Ind. Eng. Chem. Res. 45 (2005) 445-450.

[36] A.H. Jalili, A. Mehdizadeh, M. Shokouhi, A.N. Ahmadi, M. Hosseini-Jenab, F. Fateminassab, Solubility and diffusion of $\mathrm{CO}_{2}$ and $\mathrm{H}_{2} \mathrm{~S}$ in the ionic liquid 1-ethyl-3-methylimidazolium ethylsulfate, The Journal of Chemical Thermodynamics 42 (2010) 1298-1303.

[37] Y. Hou, R.E. Baltus, Experimental Measurement of the Solubility and Diffusivity of $\mathrm{CO}_{2}$ in RoomTemperature Ionic Liquids Using a Transient Thin-Liquid-Film Method, Ind. Eng. Chem. Res. 46 (2007) 8166-8175.

[38] R. Condemarin, P. Scovazzo, Gas permeabilities, solubilities, diffusivities, and diffusivity correlations for ammonium-based room temperature ionic liquids with comparison to imidazolium and phosphonium RTIL data, Chem. Eng. J. 147 (2009) 51-57.

[39] L.a. Blanchard, Z. Gu, J.F. Brennecke, High-Pressure Phase Behavior of Ionic Liquid/ $\mathrm{CO}_{2}$ Systems, The Journal of Physical Chemistry B 105 (2001) 2437-2444.

[40] S.S. Moganty, R.E. Baltus, Diffusivity of Carbon Dioxide in Room-Temperature lonic Liquids, Ind. Eng. Chem. Res. 49 (2010) 9370-9376. 
[41] M. Roustan, Transferts gaz-liquide dans les procédés de traitement des eaux et des effluents gazeux, Lavoisier, Paris, 2003.

[42] a. Yokozeki, Time-dependent behavior of gas absorption in lubricant oil, International Journal of Refrigeration 25 (2002) 695-704.

[43] J. Bedia, E. Ruiz, J. de Riva, V.R. Ferro, J. Palomar, J.J. Rodriguez, Optimized ionic liquids for toluene absorption, AIChE J. 59 (2013) 1648-1656.

[44] P.-F. Biard, A. Couvert, S. Giraudet, Volatile organic compounds absorption in packed column: theoretical assessment of water, DEHA and PDMS 50 as absorbents, Journal of Industrial and Engineering Chemistry 59 (2018) 70-78.

[45] R. Hadjoudj, H. Monnier, C. Roizard, F. Lapicque, Measurements of diffusivity of chlorinated VOCs in heavy absorption solvents using a laminar falling film contactor, Chemical Engineering and Processing: Process Intensification 47 (2008) 1478-1483.

[46] I.L. Mostinsky, A-to-Z Guide to Thermodynamics, Heat \& Mass Transfer, and Fluids Engineering in: http://www.thermopedia.com/content/696/, Diffusion coefficient, 2011, access date: 07/24/2018.

[47] D. Bourgois, J. Vanderschuren, D. Thomas, Determination of liquid diffusivities of VOC (paraffins and aromatic hydrocarbons) in phthalates, Chemical Engineering \& Processing: Process Intensification 47 (2008) 1363-1370.

[48] A. Skrzypczak, P. Neta, Diffusion-Controlled Electron-Transfer Reactions in Ionic Liquids, The Journal of Physical Chemistry A 107 (2003) 7800-7803.

[49] R. Billet, M. Schultes, Modelling of pressure drop in packed columns, Chem. Eng. Technol. 14 (1991) 89-95.

[50] R. Billet, M. Schultes, A physical model for the prediction of liquid hold-up in two-phase countercurrent columns, Chem. Eng. Technol. 16 (1993) 370-375.

[51] R. Billet, M. Schultes, Fluid dynamics and mass transfer in the total capacity range of packed columns up to the flood point, Chem. Eng. Technol. 18 (1995) 371-379. 
[52] R. Billet, M. Schultes, Prediction of mass transfer columns with dumped and arranged packings: updated summary of the calculation method of Billet and Schultes, Chem. Eng. Res. Des. 77 (1999) 498-504.

[53] R. Billet, M. Schultes, Predicting mass transfer in packed columns, Chem. Eng. Technol. 16 (1993) $1-9$.

[54] D. Song, A.F. Seibert, G.T. Rochelle, Mass Transfer Parameters for Packings: Effect of Viscosity, Ind. Eng. Chem. Res. 57 (2018) 718-729.

[55] D. Song, A.F. Seibert, G.T. Rochelle, Effect of Liquid Viscosity on the Liquid Phase Mass Transfer Coefficient of Packing, Energy Procedia 63 (2014) 1268-1286.

[56] D. Song, Effect of Liquid Viscosity on Liquid Film Mass Transfer for Packings, PhD thesis, McKetta Departement of Chemical Engineering, The University of Texas at Austin, Austin, 2017.

[57] S. Piché, B.P. Grandjean, I. Iliuta, F. Larachi, Interfacial mass transfer in randomly packed towers: a confident correlation for environmental applications, Environ. Sci. Technol. 35 (2001) 4817-4822.

[58] K. Onda, H. Takeuchi, Y. Okumoto, Mass transfer coefficients between gas and liquid phases in packed columns, Journal of Chemical Engineering of Japan 1 (1968) 56-62.

[59] M. Guillerm, A. Couvert, A. Amrane, E. Norrant, N. Lesage, É. Dumont, Absorption of toluene in silicone oil: effect of the solvent viscosity on hydrodynamics and mass transfer, Chem. Eng. Res. Des. 109 (2016) 32-40.

[60] T.T. Dang, P.-F. Biard, A. Couvert, Assessment of a Stirred-Cell Reactor Operated Semicontinuously for the Kinetic Study of Fast Direct Ozonation Reactions by Reactive Absorption, Ind. Eng. Chem. Res. 55 (2016) 8058-8069.

[61] F. Delaunay, A.-S. Rodriguez-Castillo, A. Couvert, A. Amrane, P.-F. Biard, A. Szymczyk, P. Malfreyt, A. Ghoufi, Interfacial structure of toluene at an ionic liquid/vapor interface: A molecular dynamics simulation investigation, The Journal of Physical Chemistry C 119 (2015) 9966-9972. 


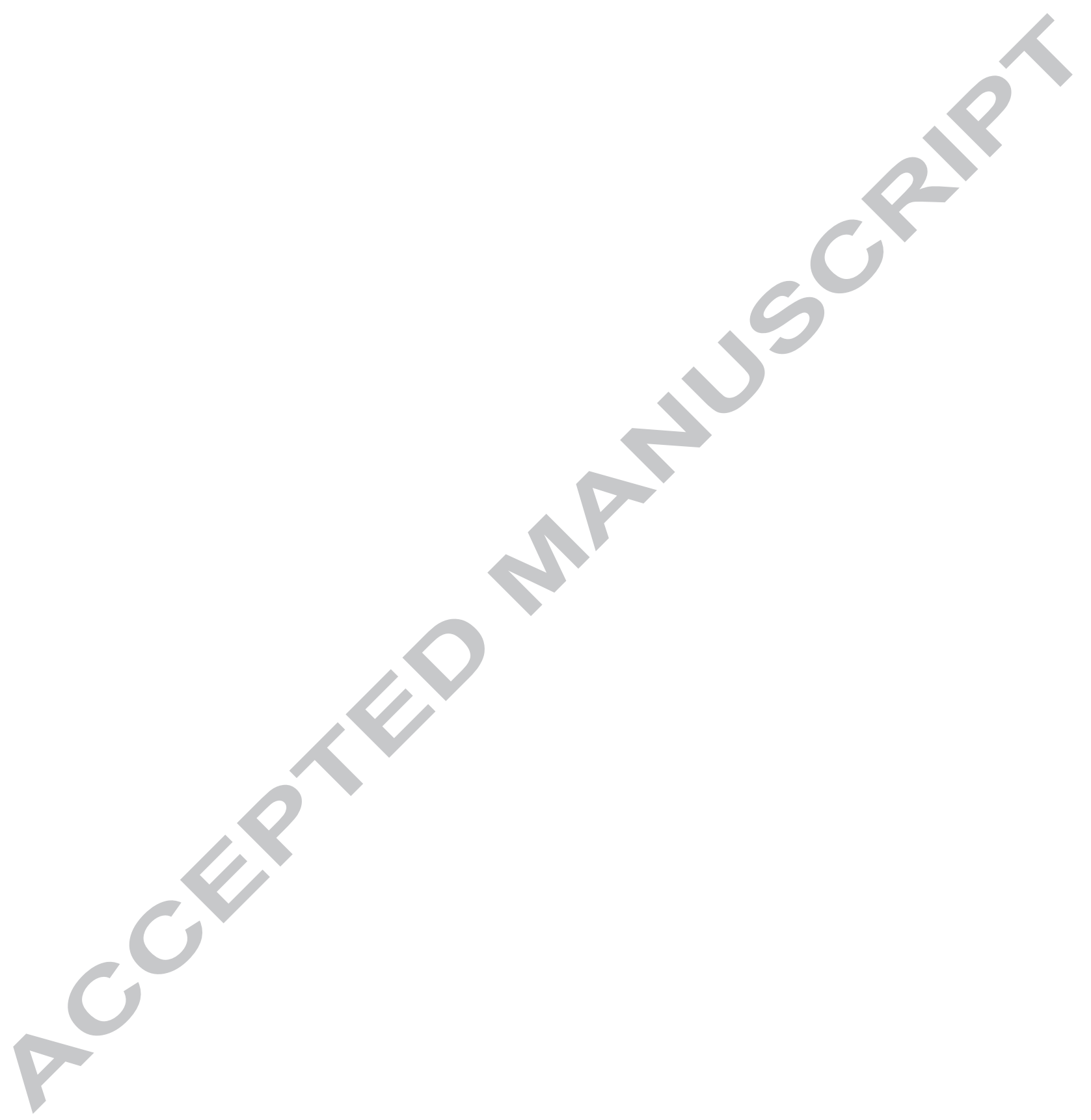




\section{Highlights}

- Toluene partition coefficients in 23 ILs were in the range 0.5-3.5 $\mathrm{Pa} \mathrm{m}^{3} \mathrm{~mol}^{-1}$

- Dichloromethane partition coefficients in 23 ILs were in the range 5-17 $\mathrm{Pa} \mathrm{m}^{3} \mathrm{~mol}^{-1}$

- VOC diffusion coefficients in the range $1-4 \times 10^{-11} \mathrm{~m}^{2} \mathrm{~s}^{-1}$ were measured in $4 \mathrm{ILS}$

- The computed toluene removal efficiency in a packed column was from 52 to $99.6 \%$

- The computed dichloromethane removal efficiency in a packed column was lower than $44 \%$ 


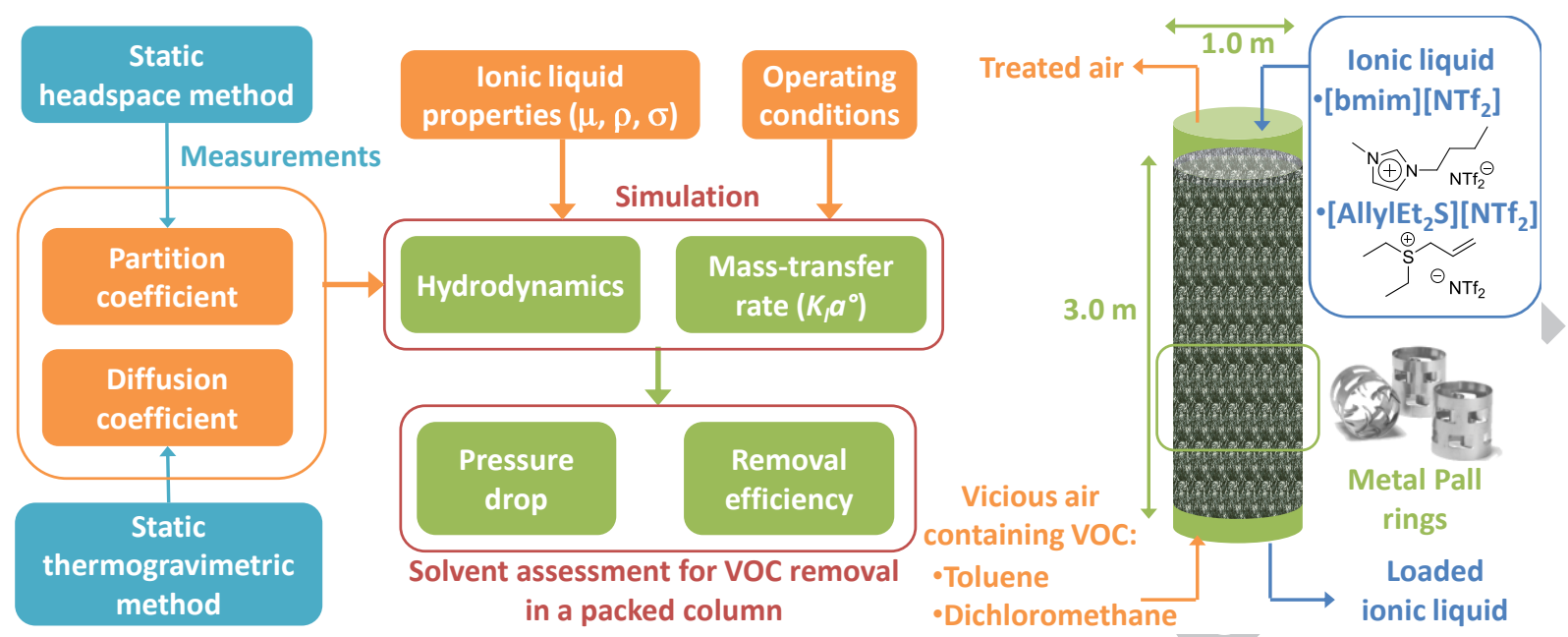

